\title{
THE EMERGENCE AND STRUCTURE OF RELIGIOUS FREEDOM IN INTERNATIONAL LAW RECONSIDERED
}

\author{
Peter G. Danchin*
}

The starting points of liberal theorizing are never neutral as between conceptions of the human good; they are always liberal starting points. And the inclusiveness of the debates within liberalism as to the fundamental principles of liberal justice reinforces the view that liberal theory is best understood, not at all as an attempt to find a rationality independent of tradition, but as itself the articulation of an historically developed and developing set of social institutions and forms of activity, that is, as the voice of a tradition. Like other traditions, liberalism has internal to it its own standards of rational justification. Like other traditions, liberalism has its set of authoritative texts and its disputes over their interpretation. Like other traditions, liberalism expresses itself socially through a particular kind of hierarchy.

\section{- Alasdair MacIntyre ${ }^{1}$}

Liberalism, when applied to the issues of citizenship and community ... is caught in a paradox: while it must assume the existence of nation-states in order to have communities within which principles of individual liberty and value neutrality can hold sway, it must at the same time studiously ignore the normative basis of such communities, since to do otherwise would be to admit that nonliberal principles of exclusion and intolerance are fundamental to a liberal state.

-Omar Dahbour ${ }^{2}$

* Assistant Professor, University of Maryland School of Law. B.A., LL.B. (Hons.) 1994, University of Melbourne, LL.M. 1998, J.S.D. 2006, Columbia University. I owe great thanks to Elizabeth Cole, Kent Greenawalt, Gerald Neuman and Jeremy Waldron for extensive criticisms and comments on earlier drafts of this article, as well as to Nehal Bhuta, Joseph Chuman, Horst Fischer, J. Paul Martin, Alice Miller, Andrew Nathan, Martin Rowe, Sanjay Ruparelia and Jacob Werksman, for their comments and insights. I wish also to express my gratitude to participants in the Rethinking Human Rights colloquium at Columbia University, and to my former colleagues and students in the Human Rights Program at the School of International and Public Affairs, Columbia University, for many discussions about these issues. All errors, confusions and omissions are my own. 1988).

1. Alasdair MacIntyre, Whose Justice? Which Rationality? 345 (U. Notre Dame Press

2. Omar Dahbour, Illusion of the Peoples: A Critique of National Self-Determination 197 


\section{INTRODUCTION}

The nature and scope of the right to freedom of religion in international law is an increasingly contested and divisive question. While virtually all scholars from an array of traditions insist that the right itself is universal, they assert quite different foundations for and often widely divergent conceptions of that right. The justifications for these differences tend to converge around two types of concern. The first relates to the particular conception of secularism seen to characterize the modern structure of international law. The claim here is that the doctrinal origins of post-Westphalian international law derive in certain important (and contestable) respects from Enlightenment critiques of Christianity. ${ }^{3}$ When these almost invisible doctrinal relationships and assumptions are brought to the foreground, we start to see the undesirable and ultimately uncheckable consequences of Enlightenment reason's "prejudice against prejudice” and the failure of its claim to objectivity. ${ }^{4}$ In this account, the notion of religious freedom as "international right" has a particular history-a time and place of origin. That history tells the story of the modernist turn to subjectivity and the ensuing difficulties of the Cartesian opposition of subject and object which today shape our international legal discourse. Richard

(Lexington Books 2003).

3. When scholars define the "public sphere" of international law solely in secular rational terms such that the "irrationality" of religion and culture are excluded, reason is said to be constructed as a unitary, closed and homogenous system with fixed boundaries rather than as a "sites of contestation and heterogeneity, of hybridization and cross-fertilization, whose boundaries are inevitably indeterminate.” Steven Lukes, Liberals and Cannibals: The Implications of Diversity 19 (Verso 2003) (discussing Benhabib’s "pluralist” view of culture in Seyla Benhabib, The Claims of Culture: Equality and Diversity in the Global Era xi (Princeton U. Press 2002)). As T.N. Madan has argued, this marks "the basic flaw of the ideology of secularism ... [that claims a] holistic, non-dualistic character, and that the separation of the domains of the sacred and the secular must be acknowledged everywhere in the same manner.” The problem, Madan notes, with "the acceptance of this position is that non-Christian religious traditions either do not make this distinction (e.g., Islam), or do it hierarchically (e.g., Hinduism), subsuming the secular under the sacred." T.N. Madan, Modern Myths, Locked Minds: Secularism and Fundamentalism in India 15 (Oxford U. Press 1997).

4. The best exposition of this view is Hans-Georg Gadamer, Truth and Method $\left(2^{\mathrm{d}}\right.$ ed., Continuum Intl. Publg. Group 1975). Gadamer challenged the familiar oppositions between reason and tradition, reason and prejudice, and reason and authority. For Gadamer, prejudices are not the remnants of an unenlightened mentality but the very things which both permit and constrain interpretation and understanding. Reason in this sense is historical and "situated," unable to free itself from historical context and horizons, gaining its distinctive power always within a living and finite tradition-the "lived world" of the individual (which precedes the individual herself). Because any interpreter views his or her object of interpretation both from and within a certain historically-situated "horizon" of expectations, beliefs and practices, understanding or meaning cannot be "objective" in the Cartesian or Enlightenment sense. Id. at ch. 4, 268-306. 
Bernstein has described these difficulties as turning on the following oppositions:

The idea of a basic dichotomy between the subjective and the objective; the conception of knowledge as being a correct representation of what is objective; the conviction that human reason can completely free itself of bias, prejudice, and tradition; the ideal of a universal method by which we can first secure firm foundations of knowledge and then build the edifice of a universal science; the belief that by the power of self-reflection we can transcend our historical context and horizon and know things as they really are in themselves. ${ }^{5}$

A strikingly similar diagnosis of these difficulties is offered by religious leaders themselves, both within and beyond the Christian tradition. From a religious viewpoint, the apparent impasse in modernity between faith and reason and between theology and scientific empiricism is traceable to the same historical moment. ${ }^{6}$ The idea that religion itself may be rational, that Christianity is a religion of Logos (religion according to reason) is, in the contemporary conceptual scheme, ruled out as a contradiction in terms. In a recent lecture made controversial for other reasons, Pope Benedict XVI attributed this state of affairs to the three attempts to "dehellenize" Christianity in the modern era: the first occurring in the sixteenth century with the Reformation attempt to "liberate faith from metaphysics"; the second occurring in the nineteenth and twentieth centuries with Kant's "modern self-limitation of reason" increasingly being radicalized by the impact of the natural sciences and leading to a concept of reason based on a synthesis between Cartesianism and empiricism; ${ }^{8}$ and the third occurring

5. Richard Bernstein, Beyond Objectivism and Relativism: Science, Hermeneutics and Praxis 36 (U. Pa. Press 1983).

6. Pope Benedict XVI has recently stated that the "Enlightenment is of Christian origin and it is no accident that it was born precisely and exclusively in the realm of the Christian faith." Cardinal Joseph Ratzinger, Lecture, Christianity: "The Religion According to Reason" (Subiaco, Italy, Apr. 1, 2005), http://www.zenit.org/article-13705?1=english (accessed Jan. 27, 2008).

7. The idea that metaphysics was a "premise from another source" led to Kant's statement that "he needed to set thinking aside in order to make room for his faith." The result was that he "anchored faith exclusively in practical reason, denying it access to reality as a whole." Pope Benedict XVI, Lecture, Faith, Reason and the University: Memories and Reflections, University of Regensburg, Sept. 12, 2006.

8. This has had two side-effects: (a) "only the kind of certainty resulting from the interplay of mathematical and empirical elements can be considered scientific"; and (b) "by its very nature this method excludes the question of God, making it appear an unscientific or pre-scientific question ... [resulting in] a reduction of the radius of science and reason.” Not only does such a view "end up reducing Christianity to a mere fragment of its former self," but

if science as a whole is this and this alone, then it is man himself who ends up being

reduced, for the specifically human questions about our origin and destiny, the questions 
in the present with the modern experience of cultural pluralism leading to acceptance of notions of "cultural relativism." "Each of these challenges has left modern thought in the position that "only positivistic reason and the forms of philosophy based on it are universally valid."10 The difficulty, however, is that the "world's most profoundly religious cultures see this exclusion of the divine from the universality of reason as an attack on their most profound convictions." 11

Arguments of this kind, whether expressed in secular or religious terms, have generated the second type of concern today evident across disciplinary fields: the question whether a universal human right to religious freedom is in some critical respects "culturally and civilizationally contingent" and, if so, whether it can be "effectively and autonomously generated from within other non-Western cultural traditions, philosophical idioms, and religious and civilizational frameworks."12 The common enemy then for both leading legal and

raised by religion and ethics, then have no place within the purview of collective reason as defined by "science", so understood, and must be relegated to the realm of the subjective. The subject then decides on the basis of his experiences, what he considers tenable in matters of religion, and the subjective "conscience" becomes the sole arbiter of what is ethical. In this way, though, ethics and religion lose their power to create a community and become a completely personal matter. This is a dangerous state of Id.

affairs for humanity ....

9. Thus, it is asserted that the "synthesis with Hellenism achieved in the early Church was a preliminary inculturation which ought not to be binding on other cultures." This is false because "the fundamental decisions about the relationship between faith and the use of human reason are part of the faith itself; they are developments consonant with the nature of faith itself." Id.

10. Id.

11. Such a conception of reason has two fatal disabilities underlying its rationality: first, it is "deaf to the divine," and having relegated religion into the "realm of subcultures," it is unable of "entering into a dialogue of cultures." Second, "with its intrinsically Platonic element, [it] bears within itself a question which points beyond itself and beyond the possibilities of its methodology.” Pope Benedict XIV, Faith, Reason, supra n. 7. Interestingly, similar arguments have been made by leaders from other religious traditions. For example the former Iranian president, Mohammad Khatami, has criticized the inability of the West to engage in a "dialogue of civilizations." During the recent Muhammad cartoons controversy, Khatami stated that "defining the question as one of freedom [of expression] amounted to brushing aside the sacred dignity that stands at the core of any religion." Karl Vick, Iran's Khatami Says Islam is the Enemy West Needs, Wash. Post A17 (Mar. 5, 2006).

12. Norani Othman, Grounding Human Rights Arguments in Non-Western Culture: Shari'a and the Citizenship Rights of Women in a Modern Islamic State, in The East Asian Challenge for Human Rights 169 (Joanne R. Bauer \& Daniel A. Bell eds., Cambridge U. Press 1999). Certain Asian theorists, for example, today address the question of how to "transform Confucian Virtues into Human Rights.” See Chung-ying Cheng, Transforming Confucian Virtues into Human Rights: A Study of Human Agency and Potency in Confucian Ethics, in Confucianism and Human Rights 142 (Wm. Theodore de Bary \& Tu Weiming eds., Colum. U. Press 1999). For an excellent discussion of the relationship between human rights and cultural diversity, see Charles Taylor, Conditions of an Unforced Consensus on Human Rights, in The East Asian Challenge for Human Rights, supra at 124; Charles Taylor, Modes of Secularism, in Secularism and its Critics 33 
political philosophers and the current Pope is some form of relativism and the common task is the justification of an Archimedean pointsome fixed and stable "foundation" - able to ground our knowledge and solve metaphysical and epistemological problems. ${ }^{13}$ Again, as Bernstein has observed, this foundation metaphor underlies many of the either/or dualisms in modern philosophy:

The specter that hovers in the background of this journey is not just radical epistemological skepticism but the dread of madness and chaos where nothing is fixed, where we can neither touch bottom nor support ourselves on the surface. With a chilling clarity Descartes leads us with an apparent and ineluctable necessity to a grand and seductive Either/Or. Either there is some support for our being, a fixed foundation for our knowledge, or we cannot escape the forces of darkness that envelop us with madness, with intellectual and moral chaos. ${ }^{14}$

With these two concerns in mind, this Article seeks to reconsider the historical emergence and evolving structure of the right to religious freedom in international law. The starting premise of my enquiry is that mainstream accounts of this history in international legal scholarship are characterized by a linear, progressive narrative that tells the story, broadly conceived, of successive paradigmatic moves from the Reformation to the Peace of Westphalia to the Enlightenment to modernity. In doing so, such accounts fail to notice a more complex narrative of genuine value pluralism which suggests that there is no simple mapping of individual toleration in international law (but rather a very complex mapping) and no single path to modernity or to the formation of the secular (but rather many paths and many negotiations at different times and in different places between politics and religion, the public and the private, reason and faith, the secular and the divine, modernity and tradition) resulting in a wide range of accommodations and forms of consensus. One of the Article's primary contentions, then, is that a critical reexamination of how, as a matter of history, the concept of religious freedom has become embedded in international law offers

(Rajeev Bhargava ed., Oxford U. Press 1998) [hereinafter Taylor, Modes of Secularism].

13. In the second Meditation, Descartes stated that

Archimedes, in order that he might draw the terrestial globe out of its place, and transport it elsewhere, demanded only that one point should be fixed and immoveable; in the same way I shall have the right to conceive high hopes if I am happy enough to discover one thing only which is certain and indubitable.

René Descartes, Meditations, in Philosophical Works of Descartes vol. 1, 198-199 (Elizabeth Haldane \& G.R.T. Ross trans., Cambridge U. Press 1969).

14. Bernstein, Beyond Objectivism, supra n. 5, at 18. 
important insights into a series of related dilemmas that confront us today.

To the extent that my argument is correct, the hope is to present a more accurate historical picture which takes account of both the discontinuity between prescriptive texts and descriptive realities and of actual religious co-existence and historical realities on the ground. The argument therefore challenges the idea of a smooth transition from the Peace of Westphalia in 1648 - the traditional birth-date of modern international law - to the post-Second World War recognition of individual religious freedom as a universally recognized human right. The traditional notion that international law first recognized the religious freedom of states, and only later that of individuals, is in this respect an overly simplistic view. The Westphalian settlement entangled religion and the state very early on and their relationship is therefore not smooth but rather fraught with difficulties. It is thus no accident that in the twenty-first century, the relationship remains full of antinomies. Indeed, this matches what is true at the level of theory, where critics of liberal theory have long asserted that mainstream accounts of human rights in international law are insensitive, and in some cases even blind, to the communal dimensions of goods such as religion.

\section{The STRUCTURE OF RELIGIOUS FREEDOM IN INTERNATIONAL LAW}

It is commonly accepted that international law was born in the modern period in 1648 at the Peace of Westphalia. This moment in history is said to mark the "great epistemological break" when religious medieval "unity" gave way to a secular system of "plural" territoriallylimited sovereign states. Between the sixteenth and eighteenth centuries, this led to the emergence of what Martti Koskenniemi has termed the "liberal doctrine of politics," the driving force of which was the attempt to "escape the anarchical conclusions to which loss of faith in an overriding theologico-moral world order otherwise seemed to lead." 15 Following Koskenniemi, I wish to pursue the contention that the emergence and changing conception of religious freedom in international law can be traced to this major structural shift and the competing theoretical positions that have flowed from it. In order to see this, we need to examine in some detail the relationship between doctrine and history. I argue that such an examination reveals two broadly identifiable narratives.

15. Martti Koskenniemi, From Apology to Utopia: The Structure of International Legal Argument 52 (Cambridge U. Press 1989). 
The first narrative - which has been instrumental in shaping contemporary international human rights scholarship-advances a linear, progressive and universalist account of Enlightenment political thought. The dominant characteristic of this story is the attempt to define the freedom of the subject-whether the individual or the state - in morally universal terms by a process of rational and ahistorical reasoning which abstracts from any particular context of social, cultural or religious ways of life. As we shall see, the method of abstraction underlying the assertion of universal moral principles can take two general forms: one projecting objective conceptions of right as an overlapping consensus between particular subjective conceptions of comprehensive culturally- and religiously-based conceptions of the good; the other asserting rationally-undeniable deontological norms which are said to be beyond consent and thus independent of any conventional particularities which are the "mere accidental clothing of reason in particular times and places.”16

The difficulty with this universalist narrative, however, is that either of these forms of abstraction depends on a second, more complex intersubjective narrative of cultural and religious pluralism integral to its structure. The two strands of universal abstraction identified above express two mutually exclusive possibilities which, paradoxically, cannot exist without each other and whose elements simultaneously require and deny each other. ${ }^{17}$ This is a complex and counterintuitive proposition which requires much further explanation. Before I proceed to give such an account, the basic point I want to stress is that once the historical and doctrinal shift has been made from moral unity to moral pluralism (i.e., once the source and authority of moral norms is recognized as plural in a system of equal, autonomous sovereigns) the idea of a single universal morality becomes fraught with difficulty. The reasons for this may be described as follows.

If "objective" or "universal" norms are to be arrived at by the overlapping consensus method, then the consent of differently-situated subjects with their own deep values is required under any type of Rawlsian-style consensus. But what if such agreement is not possible? What if, as Jeremy Waldron has recently argued, two subjects with their own comprehensive conceptions of the good assert rival (ethical) claims to freedom and autonomy which they each insist is compatible with a set

16. MacIntyre, Whose Justice?, supra n. 1, at 6.

17. See David Kennedy, Theses about International Law Discourse, 23 German Y.B. Intl. L. 353, 364 (1980). 
of compossible aims? ${ }^{18}$ Confronted by the impasse caused by the clash of two subjective wills, we are forced to turn to the second method to try and identify an "objective" or "universal" moral norm that is rationally undeniable (i.e., "reasonable" in Rawlsian terms) and thus beyond the need for consent. But how is such a norm to be arrived at in a nonsubjective way? If Waldron is correct that there is "nothing to choose" between the worlds of two differently-situated secular and religious subjects, then absent some form of express or tacit consent (which will return us to the problem we are seeking to overcome), we are faced with the conclusion that not one but several Kantian kingdoms of ends are possible. ${ }^{19}$ In other words, in the absence of an equivalent to a Leviathan at the international level, there can be no argumentative resolution of the various possible candidates for an international metaprinciple concerning the "nature" of the international community, autonomous statehood, sovereignty, human rights, etc.

This structure of argument mirrors the dialectic logic of Robert Cover's account of nomos and narrative as the means by which to understand the normativity of law in American free exercise jurisprudence. $^{20}$ In his classic Foreword to the 1982 Supreme Court Term, Cover argued that a case such as Bob Jones University v. United States $^{21}$ generates a series of paradoxes and binary oppositions as it seeks to resolve apparently opposing demands for freedom and

18. The example given by Waldron involves a conflict between the rights claims of an entrepreneurial pornographer $(\mathrm{P})$ who enjoys the public sale and display of his pornographic wares, and a devout Muslim (Q) who abhors pornography and, according to the dictates of his religious beliefs, wishes to live and raise his family in a society free of the public displays of P. In the course of an extensive analysis, Waldron demonstrates how this example poses severe difficulties for any Kantian algebraic liberalism and its twin requirements of compossibility and adequacy which seek to secure order in a way that is fair to the aims and activities of all. I.e. the Kantian objective may be stated as follows: "Act externally in such a way that the free use of your will is compatible with the freedom of everyone according to a universal law.” Thus:

the liberal claim "may be described as the task of specifying a set of constraints on conduct (call it set C), satisfying two conditions: (1) no two actions permitted by C conflict with one another; and (2) for each individual who is subject to $\mathrm{C}$, the range of actions permitted by $\mathrm{C}$ is adequate for the pursuit of his ends. I shall call these the requirements of compossibility and adequacy. Together they amount to something like algebraic specifications for the formal structure of a liberal society.

Jeremy Waldron, Toleration and Reasonableness, in The Culture of Toleration in Diverse Societies: Reasonable Tolerance 14-15 (Catriona McKinnon \& Dario Castiglione eds., Manchester U. Press 2003).

19. Id. at $29-30$.

20. Robert Cover, The Supreme Court, 1982 Term-Foreword: Nomos and Narrative, in Narrative, Violence and the Law: The Essays of Robert Cover 95 (Martha Minow et al. eds., U. Mich. Press 1993) (originally published in 97 Harv. L. Rev. 4 (1983)).

21. Bob Jones U. v. U.S., 103 S. Ct. 2017 (1983) (raising the question whether a religious school discriminating on the basis of race could be denied tax-exempt status by the IRS). 
autonomy on the one hand- "world-creating" paideic systems of normative life which are the product of strong "culture-specific designs of particularistic meaning" 22 - and community and social order on the other- "world maintaining" abstract universal norms that are justified by the need to ensure the coexistence of worlds of strong normative meaning. ${ }^{23}$ If we could imagine a world containing a singular nomos (e.g., an idealized vision of the respublica christiana), order and the meaning of value, as mediated by authority, would be one and the same. No state would be required. Indeed,

that which must be done, the meaning of that which must be done, and the sources of common commitment to the doing of it stand bare, in need of no explication, no interpretation-obvious at once and to all. As long as it stands revealed, this dazzling clarity of legal meaning can harbor no mere interpretation. The shared sense of a revealed, transparent normative order corresponds to the ideal type of the paideic nomos. ${ }^{24}$

But the "jurispotence" and unity of such a pure vision of meaning cannot exist even, as Cover is quick to note, for a fleeting moment. Differences arise immediately as challenges are made to the illusion of the identity of order with truth. Paideic unity and attachment is thus "being shattered-shattered, in fact with its very creation." 25 In order to maintain paideic coherence, dissenters advancing "flowers of normative meaning” are expelled and exiled (or worse) leading to the sectarian separation of communities, now within their own paideic nomoi. ${ }^{26}$ The respublica christiana in this way devolves into the jus publicum europaeum. This creates the problem of a plurality of meaning - the fact that "never only one but always many worlds are created by the too

22. In the "paideic" world of the nomos, law is a resource in the larger effort of a community to endow life with meaning. As an ideal-type, it suggests: "(1) a common body of precept and narrative, (2) a common and personal way of being educated into this corpus, and (3) a sense of direction or growth that is constituted as the individual and his community work out the implications of their law." This is a vision of a "strong community of common obligations" characteristic, for example, of Talmudic law and Christian conceptions of the Church where reciprocal obligations flow from commitment, not coercion, because people recognize the needs of others and respond to them. Cover, The Supreme Court, supra n. 20, at 105-106.

23. In what Cover refers to as the "imperial" legal order of the state, norms are "universal and enforced by institutions" in the interest of social order and discourse is "premised on objectivityupon that which is external to the discourse itself." This finds its fullest expression in the civil community where "[i]nterpersonal commitments are weak, premised only on a minimalist obligation to refrain from the coercion and violence that would make impossible the objective mode of discourse and the impartial and neutral application of norms.” Id. at 106.

24. Id. at 107-108.

25. Id. at 109 .

26. Id. 
fertile forces of jurisgenesis"-leading to what Cover termed the "imperial virtues and the imperial mode of world maintenance":

Let loose, unfettered, the worlds created would be unstable and sectarian in their social organization, dissociative and incoherent in their discourse, wary and violent in their interactions. The sober imperial mode of world maintenance holds the mirror of critical objectivity to meaning, imposes the discipline of institutional justice upon norms, and places the constraint of peace on the void at which strong bonds cease. ${ }^{27}$

The imperial strand is thus the product of diversity and separation as it seeks, through domination, to rescue meaning in a nomos as it disintegrates -

to maintain some coherence in the awesome proliferation of meaning lost as it is created - by unleashing upon the fertile but weakly organized jurisgenerative cells an organizing principle itself incapable of producing the normative meaning that is life and growth. ${ }^{28}$

In other words, as soon as one nomos becomes two or more nomoi and the need arises to assert imperial "objective" norms through either form of universal abstraction (i.e., whether through an overlapping consensus of pre-existing paideic meaning where "objectivity" is the product of consensual convergence, or through the assertion of an "objective" deontological norm which is itself finally paideic and thus subjectively contested), the two paideic and imperial strands are present in each form of abstraction, simultaneously requiring and denying each other.

We might say then that "universal" normative meaning is the point of convergence between two objectivities: "objective” ethical meaning derived in an ascending way from "subjective" paideic values, and "objective" moral meaning derived in a descending way from "subjective" imperial norms. Regardless of the context of justification, any assertion of objective normative meaning will thus be both externally ethical as between nomoi and internally moral as between all the members of one nomos. In this way, each nomos has internal to it a collapsing and thus transforming system of paideic norms, the diversity of which is constantly at risk of being consumed by the domination of the imperial virtues. It is for this reason that the identity and boundaries of the nomos itself are not fixed or "foundational," but constantly contested and changing as secession is threatened from within and

27. Id. (emphasis added).

28. Id. at 110 . 
domination is threatened from without.

This creates a complex and radically unstable situation with nomoi existing in different forms and standing in different relations to their members and to each other. A sovereign state, for example, is at once its own nomos (exercising imperial domination over its own members and sub-statist nomoi) and a nomos amongst others in an inter-nomian system of sovereign states. As a sovereign state, it acts internally as the imperial Leviathan adjudicating normative meaning both ethically as between itself and any sub-statist nomoi and morally in relation to all its citizens. $^{29}$ If, however, the nomos in question is the wider international system of sovereign states, then internal to that political community of what we might term "sub-global" nomian subjects there is no Leviathan authoritatively to determine either inter-state ethical norms or intra-state moral norms.

\section{A. Outline of Argument}

The implications of this argumentative structure for international legal theory are far-ranging. In this Article, however, my aims are more limited. What I seek to explore are several dimensions of the historical emergence of religious freedom in international law in order to illustrate how, if we pay greater attention to the second pluralist narrative of international legal argument, this narrative will both clarify and unsettle certain well-entrenched assumptions underlying the first, linear Enlightenment account. In particular, I advance three general arguments.

Part II examines how, in line with recent critiques by so-called "liberal nationalists," ${ }^{30}$ the linear liberal narrative treats the identity of

29. A useful illustration of this dynamic is the Shah Bano case in India: Mohamed Ahmed Khan v. Shah Bano Begum (1985) 3 S.C.R. 844. If under the principle of nondiscrimination the state does not recognize sub-statist nomoi as legal subjects with the group-differentiated right to their own nomos, then it will apply its own moral conception of norms directly to members of that group without intersubjectively mediating its interpretation of those norms with the ethical conception offered by the minority nomos.

30. Liberal nationalists recognize the ambivalence and, in general, silence of liberal theory towards the claims of majority and minority groups and have sought in response to find pathways by which to combine (liberal) individualist and (pluralist) group doctrines. Three positions, in particular, have been advanced. The first, most commonly associated with the work of Joseph Raz, Avishai Margalit and Yael Tamir, has been to draw a connection between individual liberty and the need for a collective cultural life which is said to be possible only in a nation-state. See e.g. Yael Tamir, Liberal Nationalism (Princeton U. Press 1993); Avishai Margalit \& Joseph Raz, National Self-Determination, 87 J. Phil. 439 (1990). The second approach has been to try to link democratic consent theory to national self-determination. See e.g. Harry Beran, SelfDetermination: A Philosophical Perspective, in Self-Determination in the Commonwealth (W.J. Allan Macartney ed., Aberdeen U. Press 1988). The third approach, often associated with the 
the subject of international law-the state-as prior or external to questions of justice. It is the assumption of membership in a nationstate, however, that underlies accounts of rights and obligation in the liberal state. There is, in this respect, an important and often forgotten link between doctrine and history. The most notable feature of the early modern societies from which liberal theories of rights emerged was their religious and cultural homogeneity. ${ }^{31}$ The notion that the more recent history and philosophy of liberal thought-eighteenth century Enlightenment ideas of the Rights of Man and democracy-led to the ascent of modern, tolerant, inclusive liberal states is deeply mistaken. The European state was first a nation-state which emerged in the early modern era following massive religious conflict, intolerance and exclusion. This has two direct consequences: first, assertions of "natural" or "universal" right in liberal rights discourse are the products of a distinctly particular historical and cultural nomian sphere of normative meaning and struggle; and second, such assertions either ignore or are insensitive to the plurality of assertions of right that have existed, and continue to exist, outside of struggles within Western Christianity.

Part III then considers how the idea of sovereignty itself-the notion of a system of free and equal "sovereign states"-has its historical origins in the Reformation concept of liberal toleration between competing religious nomoi (the ethical modus vivendi of cuius regio, eius religio). State sovereignty is therefore the "group rights" solution of the early liberal tradition to the problem of religious and cultural pluralism. By recognizing that communitarian freedom and autonomy (i.e., the sovereignty of states) is necessary for the flourishing and co-existence of different religious and cultural values and ways of life, liberal theory is in this respect premised on a theory of groupdifferentiated rights in international law. As already noted, however, according to the logic of a community of autonomous and equal legal subjects, the source and authority of the meaning of that sovereignty must be ineliminably intersubjective.

work of Michael Walzer, has been to view national self-determination not within an essentially individualistic conception of political legitimacy, but within a communitarian conception. See e.g. Michael Walzer, The Communitarian Critique of Liberalism, 18 Pol. Theory 6, 21 (1990).

31. This is not to say, of course, that such states were entirely religiously and culturally homogenous. In Great Britain, for example, religious diversity (mainly within Christianity) became an important factor from the seventeenth century onward, and the France of the ancien regime cannot be said to have been completely culturally homogenous. The more general point is that this diversity, to the extent that it existed, did so within the context of broadly Christian emergent European nation-states. 
If this is correct, then in seeking to understand the doctrinal history of religious freedom in international law, we need to pay more careful attention to the normative consequences of the shift from the ius gentium of the respublica christiana to the ius inter gentes of the jus publicum europaeum. Following the Peace of Westphalia, no longer did the law govern a religiously-based, homogenous Christian nomos that received its validity from God as mediated by the right ecclesiastic and secular authorities claiming universal jurisdiction. It now regulated the relationship between European territorial states realizing a sharp separation between secular and Church jurisdiction. This, I suggest, had two interrelated jurisgenerative dimensions —one as between European states inter se (i.e., as between the newly recognized political subjects of the former unified Christian nomos), and the other as between European states taken as a whole and non-European peoples and territory (i.e., as between European states separated as political subjects but united by their background identity and culture and those peoples and territories lying outside of Western Christendom).

In the case of inter-state relationships, culturally European and religiously Christian background conditions underlay - and perhaps made possible - the Enlightenment idea of a "universal" rational consensus on cross-cultural moral judgments and principles of international justice. (Yet, as we today recognize, the social contract and natural law traditions always involved and continue to yield a plurality of accounts of the relationship between the right and the good, even as between European states.) Whether they were justified as secular abstractions from older Christian theologies or as deontologically independent "natural law" principles, classical liberal claims of the priority of universal right and neutrality on the good were thus premised on a deeper collective religious and cultural particularity. Modern "international law" constitutes, in this respect, the projection of the doctrines and norms of the jus publicum europaeum into a wider globalizing world of both non-European and late modern societies in which there exists a deeper pluralism of ways of life and diversity of values and beliefs. We should expect, therefore, that any (unforced) claims of liberal neutrality and principles of right and justice that portend to stand aloof from conflicts over the good are likely to be strongly contested in those states and societies with their own comprehensive culturally- and religiously-derived normative systems.

In the case of relations between European and non-European peoples, Enlightenment commitments to purportedly ahistorical, rational and universal moral norms-now conceived as independent of any 
particular way of life or religious and cultural differences-in combination with a "civilizing" imperial mission premised on a doctrine of historical progress, were used to justify subjugation. Here, the structure of legal argument previously discussed helps to explain an enduring paradox: How is it possible that a moral and political doctrine premised on the universal and equal moral status of human beings could not only exclude certain peoples from such norms, but actually be deployed to justify cruel acts of slavery, dispossession and even genocide? The reasons, I believe, are tied in part to the Enlightenment's severing of the connection between the human self and cultural diversity — what Sankar Muthu describes as the uniquely rational ideal that cultural difference is not integral to the universal human subject. ${ }^{32}$ Not only did this proposition deny the cultural and religious sources of, and authority for, (European) "universal" moral norms, it rendered impossible the relevance of non-European "culture-specific designs of particularistic meaning" as sources of and authority for such norms. ${ }^{33}$ Just as Muslim girls in contemporary European states are now being asked (or compelled) to liberate themselves from the oppression and cultural backwardness of the hijab, ${ }^{34}$ non-European peoples in the Age of Empire were required to eschew their "unimportant, and even

32. Muthu's work seeks to "pluralize" our understanding of the Enlightenment through exploration of the anti-imperial political thought of philosophers such as Diderot, Kant and Herder. See Sankar Muthu, Enlightenment Against Empire (Princeton U. Press 2003).

33. In this respect, the logic of the argument I am advancing is similar to the critiques of formal equality advanced by critical legal scholars. Let us return, for example, to Waldron's example discussed above of the two-subject case of $\mathrm{P}$ and $\mathrm{Q}$ where

the rights claimed by $\mathrm{P}$, as necessary for the pursuit of his aims, may be different from the rights claimed by Q, as necessary for the pursuit of hers. Of course, the rights claimed by $\mathrm{P}$ will be correlative to duties imposed on $\mathrm{Q}$ and vice versa. But although P's rights are correlative to Q's duties, and P's duties correlative to Q's rights, P cannot simply take the set of rights he has and the set of duties he has and, replacing proper names with variables, regard them as correlative. He is therefore no longer able to work out what duties he has simply by considering what would be correlative to the rights he claims. He must really pay attention to the situation and needs of the other person, Q, because these may differ significantly from anything he can extrapolate from his own case, or any understanding of what he would demand if we were standing in their shoes. Waldron, Toleration and Reasonableness, supra n. 18, at 35 n. 10. (emphasis added). If we substitute "European states" for P and "non-European peoples" for Q, the argument is the same. An abstract conception of universal liberty (i.e., the universal proposition that "everyone is to have whatever is necessary for the pursuit of his or her own good") will not entail equal or uniform rights of differently-situated subjects at a more concrete level. As difference theorists have argued, this requires a conception of justice that pays great attention to the concrete and the particular and emphasizes context-sensitive judgments regarding claims of culture and identity arising from different conceptions of the good.

34. See Peter G. Danchin, Suspect Symbols: Value Pluralism as a Theory of Religious Freedom in International Law, 33 Yale J. Intl. L. 1 (2008). 
undignifying, cultural ephemera" in favor of "civilized" norms and practices. $^{35}$ Indeed, on account of their very humanity, Enlightened peoples bore the burden of aiding their convergence towards that single form of social life we know as "civilization."

This decontextualized view of universal rationality is evident in two spheres. First, we see it in the contentious and often overlooked struggles between Enlightenment and counter-Enlightenment thinkers in the eighteenth century over how to understand the connection between human nature and religious and cultural diversity. Dissenting thinkers in this period posited that differences in social practices and cultural norms are often incommensurable and that there are no a priori universal standards that can be used to rank them. ${ }^{36}$ This sensitivity to pluralism did not, however, render such positions culturally "relativist" in any disreputable sense. Egalitarian and humanitarian norms were necessary to counter-Enlightenment thought despite their exclusionary tendencies precisely because they countered the idea that "non-Europeans were inherently inferior in some fundamental sense." not sufficient to defend non-Europeans against European imperial power without reconceptualizing the relationship between cultural diversity and humanity: the idea that "what most noticeably differentiates humanstheir various and often incompatible or competing cultural systems of meanings and values - is integral to the human condition."38 And second, the particularity of the Enlightenment becomes starkly evident in the different accounts of toleration and forms of religious co-existence developed by non-European peoples (I consider, in particular, the millet system in the Ottoman empire below), which together suggest the possibility of a plurality of universalisms and forms of "secular" abstraction from strong religious and cultural bonds.

Finally, Part IV considers the implications of the more recent articulation at the international level of individual freedom of conscience which, while tracing its roots to Enlightenment political thought in the

35. Muthu, Enlightenment Against Empire, supra n. 32, at 273.

36. Id. at 275. As Muthu states, under "conditions of incommensurability, one can at best draw upon partial, incomplete, and plural standards, since there is no single norm, principle, or value with which they can be compared and judged." Id.

37. Id. at 274

38. To view human beings as fundamentally cultural agents "acknowledges their status as artful, reasoned and free individuals who are partly shaped by their social and cultural contexts, yet who also through their actions and through changing perceptions alter such contexts themselves." Id. at 274. Here again we see a reflection of Cover's idea of the logic underlying the transformative structure of legal argument itself: that there is an ineliminably intersubjective and symbiotic relationship between human freedom and rational autonomy on the one hand, and human paideic social and cultural contexts on the other. 
eighteenth and nineteenth centuries, only became established in international law in the post-Second World War era. Given the analysis above, there are compelling reasons to take seriously the well-known communitarian critiques of liberalism. We should recall in the international context, for example, Alasdair MacIntyre's argument that the liberal claim to morally justified ethical neutrality and toleration conceals the fact that liberalism is based on a "particular conception of the good life" and is therefore one tradition among others without any necessary moral claim to priority. ${ }^{39}$ To the extent MacIntyre is correct, his work should alert us to the danger of uncritically advancing one ethical account of individual freedom and personal autonomy as a universal moral norm in the vastly more religiously and culturally diverse nomos of international law. The danger, as Michael Sandel has claimed, is that other ethical conceptions of a norm such as freedom of religion or belief that do not conform to liberal theories of the goodespecially those premised on "deep" (i.e., sensitive and "public") communal bonds-will thereby become marginalized and excluded. ${ }^{40}$

The normative structure of international human rights law concerning freedom of religion or belief is not, however, exclusively "liberal" in the sense of protecting only individual freedom and autonomy. International instruments contain norms protecting the right of peoples to self-determination and the rights of religious, linguistic and cultural minorities. These collective rights are the legacy of the interwar period minorities system instituted under the League of Nations and reflect the long history in Europe of struggles for political freedom and recognition between various religiously- and culturally-situated national majorities and minorities. It was only in the post-Second World War era following the collapse of the League that the idea of "groupdifferentiated" rights fell out of favor and was seen by the Allied powers as one of the contributing causes of the war. The 1948 Universal Declaration of Human Rights, for example, focused almost exclusively on the rights of the individual and was drafted without provisions on the rights of peoples or minority groups. It was not until the completion and entry into force of the two Human Rights Covenants in 1976 that collective rights protections in the form of Articles 1 and 27 of the International Covenant on Civil and Political Rights (ICCPR) were once again recognized in international law.

39. MacIntyre, Whose Justice?, supra n. 1, at 345.

40. See Michael Sandel, Religious Liberty - Freedom of Conscience or Freedom of Choice?, 3 Utah L. Rev. 597 (1989). See generally Michael Sandel, Liberalism and the Limits of Justice (Cambridge U. Press 1982). 
The result is that today, international human rights law on freedom of religion and belief reflects the tension between these two "liberal" and "communitarian" strands of doctrinal history-one narrative expressing the Enlightenment commitment to individual freedom and moral autonomy, the other narrative expressing the counterEnlightenment concern for collective cultural and religious diversity. In this respect, the law both is a useful corrective to excessively individualistic approaches to the question of religious freedom and at the same time is open-textured and radically indeterminate in its provision for group-differentiated claims. These two clusters of norms merely reproduce the dilemmas we are grappling with within the structure of legal argument without providing any substantive means for the resolution of conflicts between rights in specific contexts. For the norm of freedom of religion or belief to have any meaning, it must therefore advance "external" or "objective" values that can only be generated through ongoing intersubjective discourse and the search for consensus both within and between different nomian sovereign spheres of thick paideic meaning.

\section{Religious LiBerty IN THE EARLy MODERN PERIOD}

Let us now turn to the first argument: the question of religious liberty in the early modern period. Here, and in the following sections, I rely on Martti Koskenniemi's critical doctrinal history of international legal argument in From Apology to Utopia. ${ }^{41}$ Central to Koskenniemi's analysis is the distinction between early scholarship, which shared the "pre-liberal assumption of an objective, universally binding code which preexists man but is graspable by him through faith or recta ratio," and the classicism born in the wake of the 1648 Peace of Westphalia, which sought to justify normative order by building on the equal right to sovereignty and independence (i.e., "liberty") of States. ${ }^{42}$ Koskenniemi's basic argument is that the history of international legal theorizing is a "continuous flow of transformations, or movements, from a descending position to an ascending one and vice versa." 43

The "descending" strand seeks to justify assertions of order and obligation on the basis of "objective" or "universal" norms of justice that are anterior or superior to the particular behavior, will, or values of States. Here again we see Cover's world-maintaining imperial virtue

41. Koskenniemi, From Apology to Utopia, supra n. 15, at ch. 2.

42. Id. at 73, 84 .

43. Id. at 84 . 
which seeks to guarantee the law's binding force. The "ascending" strand takes as given the existence of States and attempts to construct an "objective" or "universal" normative order on the basis of actual State behavior, will, and values. Here again, we see Cover's world-creating paideic virtue which seeks to guarantee the law's concreteness though State consent. This doctrinal structure, in other words, mirrors the relationship between the two narratives discussed above. Accordingly, no classical doctrine or position in international law is either solely ascending or descending; but rather, each contains both ideal-typical strands within itself in a constantly evolving and shifting process of reconciliation.

This is not, however, how international legal argument was understood in the early modern (pre-Westphalian) era. Instead, preclassical writing was shaped by two dominant characteristics: first, a purely descending argument from divine law and second, the justificatory role of authority. Thus, the liberal distinctions which we today draw between freedom and order and public and private were nonexistent in medieval thought. ${ }^{44}$ To speak of a "personal right" to, or "private realm" of, liberty of conscience with independent legitimacy as against the world at large would therefore be meaningless within such a conception of social order.

The two early international legal theorists of most significance for the purposes of my argument are Francisco de Vitoria (1480-1546) and Hugo Grotius (1583-1645). It is commonly suggested that Vitoria and Grotius employed opposing modes of argument, the former deriving the content of law through Christian revelation, the latter through a combination of religious and secular authority with the issue of hierarchy left open. Grotius is accordingly credited with being the early writer who elevated reason above revelation through his assertion that natural law would exist even on the assumption-per impossible-that

44. Koskenniemi describes the main features of international law in medieval thought as follows:

"[O]rder" was a natural state of affairs, existing by the force of creation and discoverable in the natural arrangement of things and men through faith or recta ratio. If doubt arose, it could always be dismissed by appeal to the Church's or the Emperor's authority. Behind this authority stood the Christian idea of a Civitas maxima which both legitimized and constitutionalized it. Different institutions exercised powers in a system of mutual control, each submitted to legitimation proceeding "downwards" from the highest commands of divine law. Political order participated in the general arrangement of things in nature as well as in society, not yet differentiated from each other. It was visible in the hierarchical systems of loyalty between levels of society, accompanied by oaths of allegiance the network of which was sanctioned by Christian ideas of justice. Id. at 56-57. 
there was no God. ${ }^{45}$ But in actual terms, their argumentative structure was similar in that all norms and all legitimate authority derived from the same source, whether "faith" or "reason."46

The result of this structure was an apparently unitary, communitarian conception of a universal, normative code derived from God which drew no distinction between the domestic and the international, the moral and the legal, or the public and the private. The ius gentium was therefore a universal inter-individual rather than international law. This did not mean of course that all law was regarded as "divine" or "natural," and indeed all the early writers developed complex distinctions between divine, natural, human and international law. Rather, they held that while the content of the law may be found in different sources, its authority derived from a relevant descending strand of justification. ${ }^{47}$

45. The original phrase is "etiamsi Deus non daretur": "What we have been saying would have a degree of validity even if we should concede that which cannot be conceded without the utmost wickedness, that there is no God. ...” See Hugo Grotius, De Jure Belli ac Pacis, Libri Tres, vol. 1, Prolegomena § 11, at 13 (Francis W. Kelsey trans., Classics Intl. L. No. 3, Clarendon Press 1925). Grotius can be seen here to be building up his account of natural law layer by layer through notions such as mutual sociability and mutual aid. While he could get this far without God, Grotius did, however, hold to God's existence and repeatedly asserted that the law's ultimate source is divine will and that this basis was necessary for a complete theory of the natural law. He thus immediately follows the above passage in the Prolegomena by saying that:

Hence it follows that we must without exception render obedience to God as our Creator, to Whom we owe all that we are and have; especially since, in manifold ways, He has shown Himself supremely good and supremely powerful, so that to those who obey Him $\mathrm{He}$ is able to give supremely great rewards, even rewards that are eternal, since $\mathrm{He}$ Himself is eternal. We ought, moreover, to believe that He has willed to give rewards, and all the more should we cherish such a belief if He has so promised in plain words; that He has done this, we Christians believe, convinced by the indubitable assurance of testimonies. Id.

46. Koskenniemi argues that "faith" and "reason" are not fundamentally different categories in the pre-classical lawyer's argument. The authority of norms or the legality of actions are decided by looking at the standard's content to see whether it reproduces the demands of faith or reason, not by having recourse to independent legislative authority. Whether the argument refers to God or nature is immaterial to the argumentative structure:

The faith which links normative conclusions to God and the reason which links them to nature act in a similar fashion. Both assume that obligation is something transcendental and discoverable in immediate reflexion or deduction from first principles. In fact, keeping the two apart seems both difficult and, for the conclusions reached, irrelevant. In one way or another, natural law becomes derivation of divine law while the content of the latter makes itself known in the former. Both take argumentative positions in contrast to non-normative, arbitrary will.

Koskenniemi, Apology to Utopia, supra n. 15, at 75.

47. Thus, the "unity of law and morality is the unity of reason (or revelation) and right will." । For Grotius, natural law may be discovered by a priori reasoning as well as a posteriori evidence. Its deduction from first principles is just as "objective" as drawing inferences about it from sovereign behavior. This is natural as the sovereign is merely an agent of the normative order." 


\section{A. Francisco de Vitoria and Pre-classical Argument}

The implications of this structure can best be seen in the preclassical conception of sovereignty. Under a purely descending, naturalist (or divine) argument it was unnecessary to reconcile the "demands of freedom and order or [to] balance[e] the freedoms of two or more sovereigns." The Prince's sphere of liberty or "sovereignty" had no independent normative status but rather described the "powers and liberties which the Prince was endowed with by the normative code." 49 As all men are united by a divine order, the "sovereign's authority is not so conceived as to establish a boundary between international and municipal law" and, accordingly, neither Vitoria nor Grotius experienced any difficulty in discussing "inter-sovereign relations, relations between the sovereign and his subjects or even family relations by reference to the same or interdependent rules." ${ }^{\circ 0}$

The impossibility of a conflict between the freedom of two sovereigns can be seen in Vitoria's discussion of Spanish rights in America. For Vitoria, both Indian and Spanish sovereignty were

Id. at 76-77.

48. Thus, the "problem of indeterminacy of legal rules is located at the realm of faith and solved by recourse to authority. Only when the sense of disparity between the normative outcomes and the perceived reality became too great, faith could be questioned and a transition to classical discourse could take place.” Id. at 73-74. While a consensus gentium, or custom, may be evidence of rules, it has no independent authority and cannot be law simply by consensus. The authority of all law proper, or ius gentium, (whether divine, natural, human, or international) derives from the same source: an immanent divine order. "The possibility of conflict is defined away: all law stems from the same source. By definition, then, human law cannot enter into conflict with natural law because if it entered, it would not be 'law.' Ius gentium is proper law, not contract, and therefore not binding simply because willed." Id. at 77.

49. Id. at 192. Thus, the

Prince's will has no independent authority following from the "inside" of his postulated freedom, no "reserved domain" which would emerge in contrast or conflict to the normative order. His authority is delegated competence, constantly controlled by the Id. at 76 .

normative order. The Prince is an agent of the normative order.

50. See Francisco Vitoria, De Indis et de Iure Belli Relectiones, 1696, § I, 120-122 (John Pawley Bate trans., Classics of Intl. L., no. 7, Carnegie Instn. 1917); Grotius, De Jure Belli ac Pacis, supra n. 45, Prolegomena § 16, 15; Id., bk. I, ch. I, § X, at 38-39. The ius gentium of early international lawyers was, in this respect, "not so much international as inter-individual law, applicable on a universal scale.” Koskenniemi, Apology to Utopia, supra n. 15, at 76 n. 95 . The liberal distinction between the public and the private was thus completely absent.

There was no individual freedom, no private realm which would have independent legitimacy as against the world at large. If there was freedom, it was allocated from above and retrievable at any time. It was not a personal "right" but rather a competence or an authorization to do what was necessary.

Id. at 57 (citing Richard Tuck, Natural Rights Theories: Their Origin and Development $7 \mathrm{ff}$. (Cambridge U. Press 1979)). 
"coterminous with each other" and the question to be determined was "how God had given possession to the Indians and what conditions the Spanish must fulfill in order to gain possession rightfully." 51 The contrast with modern discussions of sovereignty is striking:

There are no elaborate definitions of "statehood"-an effort only meaningful if we regard that an abstract category such as "State" is relevant per se to infer what rights people have. For Vitoria, "statehood" is no starting-point for normative deductions. It can become such only after legal concepts receive autonomy and legitimacy within a neutral and universally applicable system of such concepts. For Vitoria, the problem was which rights God had given to Indians and to the Spanish. There was no assumption that these rights would be symmetrical or depend upon some formal status vested in the Spanish and the Indians respectively. ${ }^{52}$

Similarly, this structure of argument shaped Vitoria's understanding of freedom of religion in the form of conscientious objection (i.e., the problem of how to reconcile the distinction drawn today between private conscience and public legal duty). Given the impossibility of a conflict between legal and religious obligation in early scholarship, duties which conflicted with faith were simply defined away as non-duties. Thus, Koskenniemi describes Vitoria's argument as follows:

[F]irst ... there exists a duty of subjects to follow the Prince to war. This duty extends to cases where there is doubt about the war's justness. But if the subject is convinced of the war's unjustness he ought not to serve in it. The threat that this poses to the order is dealt with by the strong view that subjects in general should not decide this matter themselves but leave it to the Prince's counselors, assumed to be Christian elders. But if such conviction is genuine-a matter to be decided by the Church's decision as to what is needed to show faith or heresy-it overrides legal obligation, making such obligation non-existent. ${ }^{53}$

51. Vitoria, De Indis, supra n. 50, § I, 116, 120-128. As God had given territory to Indians, he thereby "established their legitimate authority" and any claims to interfere with it, including those of the Pope and the Emperor, were invalid ab initio. id. § II, 129-139.

52. Koskenniemi, Apology to Utopia, supra n. 15, at 79.

53. Id. at 78. See generally Vitoria, De Indis, supra n. 50, Second relectio, § 26-31, at 174177. Note that while Vitoria believed that difference of religion was not a cause of just war, he did believe that Christians had a right to preach the Gospel to unbelievers, a right which included using the means of war. Interestingly, he also argued that war and the imposition of new rulers were justified to stop native rulers from enforcing human sacrifices or engaging in cannibalism. Evans regards this as a "move away from the medieval idea of a theological just war concept and a move towards a secular concept based upon natural law.” Malcolm Evans, Religious Liberty 
In no way did this argument give rise to any personal claim of right on account of the objector's private conscience. The suggestion was rather that only true Christian belief could, and indeed must, override any purported legal obligation. The distinction between faith and sin, as in Vitoria's treatment of Indian and Spanish sovereignty in America, was therefore the controlling distinction. ${ }^{54}$

\section{B. Hugo Grotius and the Transition to Classical Argument}

As with Hobbes in political theory, the seventeenth-century jurist Hugo Grotius was the transitional figure in international law between the descending, nonliberal order of medieval thought and the ascendingdescending order of the classical liberal period. In order to understand the nature of this transition, it is important to consider the historical context in which Grotius was writing. Having been born into the sixteenth century when Luther's ninety-five theses challenging papal corruption caused a split in the Western Christian church, Grotius's most famous work, De Jure Belli Ac Pacis, was published in 1625 in the midst of the horror of the Thirty Years War (1618-48), which divided Europe among rival religious denominations. ${ }^{55}$ Grotius was therefore driven by the overwhelming desire to find legal and political solutions to the problem of inter-religious conflict in the turbulence of the late Reformation. This context required new approaches to questions regarding the basis of legal obligation and the just war doctrine.

A central question for Grotius was how to deal with the apparent conflict between a Prince's acts-as opposed to those of a tyrant or someone acting in his private capacity — and divine or natural law in a

and International Law in Europe 33 (Cambridge U. Press 1997).

54. Note also Suárez's asymmetrical sovereign right of intervention:

If an infidel Prince prevents his population from being converted to Christianity, any

Christian sovereign may intervene. But an infidel Prince may not intervene if the

Christian sovereign does not allow his subjects to be converted into heretics. Proof of

this is that to prevent Christ's law from being accepted does irreparable harm while prevention [of] other law's acceptance does not.

Koskenniemi, Apology to Utopia, supra n. 15, at 79 (quoting Francisco Suárez S.J., De Triplici Virtute Theologica, Fide, Spe et Charitate, 1621, Classics Intl. L. vol. II, no. 20 (1944) § V, at 826-827). See further John P. Doyle, Francisco Suárez on The Law of Nations, in Religion and International Law 103-120 (Mark W. Janis \& Carolyn Evans eds., Martinus Nijhoff Publishers 1999).

55. As Janis observes, "[i]n modern times, only the $20^{\text {th }}$ century begins to rival the $17^{\text {th }}$ in terms of its bloodshed. In the largely Germanic territories of the Holy Roman Empire, 'the carnage and desolation were probably greater than men had ever wrought in one generation in any land before."' Mark W. Janis, Religion and the Literature of International Law: Some Standard Texts, in Religion and International Law, supra n. 54, at 121, 122 (quoting Will \& Ariel Durant, The Age of Reason Begins 567 (Simon \& Schuster 1961)). 
Europe where many sovereigns were committing blatant violations of natural law and still remaining as sovereigns. ${ }^{56}$ He therefore questioned the asymmetry between sovereigns and drew a new distinction between a "just" war and a formally "legal" war, the latter resting on the mere fact that it was conducted by sovereign authority. ${ }^{57}$ In doing so, he was able to ensure that that the laws of war (jus in belli) were applicable in any armed conflict between sovereigns. ${ }^{58}$ This represented an attempt to maintain the just/unjust war distinction of the normatively controlling natural order while at the same time recognizing the formally legal character of sovereign acts, even unjust acts. Hence:

unjust war may produce titles which are legal in the sense that the wronged sovereign's claim remains non-enforceable. Grotius attempts to justify the distinction between non-enforceable (natural) law and formally legal acts by contending that unless the belligerents are treated equally and the question of the justice of the war is set aside, more chaos and suffering will ariseespecially as there is no central authority to decide the matter. ${ }^{59}$

The underlying struggle here was to deal with the unfolding consequences of a loss of faith in a singular concept of the just and the difficulty of reconciling the "Christian conception of the unity of the human race with the historical fact of the distribution of power among sovereign States."60 If previously conflict between a sovereign's

56. For the early lawyers, war was not a conflict between legitimate sovereigns but a public procedure against a wrong-doer. There was thus no conflict or symmetry between sovereignties and a war could not be objectively just on both sides. If a sovereign erred in making his judgment, however, he could be excused. This did not change the nature of the war as a public procedure but it absolved the sovereign who had no just cause and allowed him to remain sovereign. Vitoria, De Indis, supra n. 50, Second relectio, § 32, at 177; Suárez, De Triplici, supra n. 54, § VI, at 828-830; Grotius, De Jure Belli, supra n. 45, bk. II, ch. XXIII, at 565-566.

57. As Janis notes, this move represents Grotius's attempt to overcome the cynicism of the philosophy of Euphemus that "in the case of a king or imperial city nothing is unjust which is expedient.” Grotius, De Jure Belli, supra n. 45, Prolegomena, § III. Janis, Religion and Literature, supra n. 55, at 123.

58. Grotius, De Jure Belli, supra n. 45, bk. III, ch. IV, at $641 \mathrm{ff}$.

59. Koskenniemi, Apology to Utopia, supra n. 15, at 82 (citing Grotius, De Jure Belli, supra n. 45, bk. II, ch. XXIII, § II, 558; bk. III, ch. IV, § IV, at 644).

60. Charles de Visscher, Theory and Reality in Public International Law 13 (P.E. Corbett trans., rev. ed., Princeton U. Press 1968). This same shift can be seen in the writings of Alberico Gentili (1552-1608), a Protestant jurist who rejected the claim that differences of religion could justify wars between States and who even called for the toleration of religious differences within States. As Evans notes, however, in the

Reformation and the wars of religion that it spawned, this was more of a plea than an observation. Nevertheless this marks the beginning of a shift in perspective. The decay of the concept of empire and papacy as forces uniting Christendom is reflected in the separation of temporal and spiritual power. In doing so, Gentili prefigured the emergence of the secularized society of nations. 
freedom and the normative order had been impossible - the resolution of actual conflicts was achieved by the exercise of either revelation or reason to determine what the normative order required-now in the wake of the bloodshed of the Thirty Years War, the latent conflict between sovereign freedoms or sovereignty and the normative order was surfacing. While Grotius himself did not go this far, we can see in his work the early signs of the need to recognize war as a conflict between formally equal sovereigns and to confront the question of how to "balance" the freedoms of sovereigns. To do this, however, required rethinking the primacy of the normative order (now perceived as subjective and hence utopian) and to start an international legal discourse instead from the sovereign's assumed subjective authority. Such a move from a descending to an ascending initial strand of justification would only follow in the post-Grotian classical scholarship of Locke and Vattel and their followers.

As noted above, Grotius is commonly regarded today as the first international legal theorist to have "secularized" the law of nations. There is considerable disagreement on this point in the literature, however. The debate turns on the basis of the obligation of states to international rules such as, for example, the doctrine of religious toleration. What I wish to suggest is that this debate is in fact merely a reflection of the two perspectives from which one might view the ascending-descending structure of "objective" abstraction that we have been discussing. In this respect, both views are "correct" although incomplete and unable to exist without the other while at the same time denying each other. Both paideic and imperial strands are thus contained within each perspective, though in different ascending and descending forms asserting "universal" or "secular" norms abstracted from the comprehensive but disintegrating Christian nomos in which Grotius was theorizing.

On one view, Grotius's work is said to fall within the "nonpolitical" or "common ground" approach which emerged as a consequence of the savage European wars of religion. This is perhaps one of the earliest examples of the attempt to articulate a Rawlsian-type overlapping consensus drawing on the different "deep" religious values and traditions of the mid-seventeenth century in the search for an "ethical" norm of coexistence between now "sovereign" differentlysituated nomoi. As Charles Taylor argues, the aim was for Christians of all sects (arguably all theists) to agree upon grounds of coexistence and 
political order.

This could be grounded on a version of natural law, which like Aquinas' was indeed conceived as being independent of revelation, but still connected to theism, because the same reasoning which brings us to the law brings us to God. The crucial step that needed to be taken was to hold that the political injunctions that flowed from this common core trumped the demands of a particular confessional allegiance. So while the proponents of struggle could feel justified in tearing up treaties as soon as it was advantageous to do so, on the grounds that you don't need to keep faith with heretics, the defenders of the common ground argued that our obligation to God required that we keep our word to fellow human beings (or perhaps theists), and that this trumped any demands stemming from confessional allegiance. $^{61}$

In line with this view, Janis has suggested that while Grotius's theory of a law of nations, based on the consent of sovereigns, was meant to be "more or less religiously neutral," it drew heavily on religious references and proofs so as to justify "legal principles which could tolerate both religious and political diversity among the nations." 62 He thus wrote outside of a single Christian denomination because he sought to establish a law of nations that would bind Catholics, various Protestants and perhaps even non-Christians alike. While at a time of rigidly conservative faiths, he may have been perceived to be "outside" ordinary religion, he in fact

brought religion to the discipline not to exclude other religious groups (be they Calvinists, Catholics, Jews or Moslems), but to show that his religion, a liberal and universal faith, proved that the law of nations was meant to include all peoples. ${ }^{63}$

61. Taylor, Modes of Secularism, supra n. 12, at 31, 33 (arguing that Pufendorf and Locke offered versions of Natural Law of this kind).

62. Janis, Religion and Literature, supra n. 55, at 123, 125. In this way, his legal principles were "especially valuable in an age when Europeans were seeking ways to legitimate and structure a society where competing religious and political institutions needed to coexist." Id. at 126.

63. Id. at 125. Evans, however, argues that it

may be doubted whether [Grotius] could have accepted the justness of a war waged by non-Christians against Christians who had acted with similar "cruelty" towards them. Indeed, he claimed that there was a duty of Christian States to protect themselves against the enemies of Christianity. Whilst it might be true that Grotius advocated "peaceful coexistence" with non-believers, this did not imply equality, or even toleration.

Evans, Religious Liberty, supra n. 53, at 40-41. But cf. Arthur Nussbaum, A Concise History of the Law of Nations 110 (Macmillan Co. 1954) (arguing that "[i]n fact, tolerance is the outstanding feature of Grotius' work"). 
The opposing view is that Grotius was one of the earliest exponents of the attempt to define an "independent political ethic" built on reasons separate from any and all religious beliefs and premised instead on those features of the human condition from which we may deduce "certain exceptionless norms, including those of peace and political obedience." 64 This assertion of a rational "secular" deontological norm is said-as is necessary for a world maintaining imperial virtue-to be beyond consent and able to resolve conflicts between conventional principles when an overlapping consensus proves impossible. Taylor himself appears to place Grotius in this category. ${ }^{65}$ So, too, do Tuck-who argues that Grotius's argument offers reasons to accept certain norms regardless of the dictates of religion ${ }^{66}$-and Nussbaum - who concludes that Grotius's international law, while "inspired by Christian ideals . . . was secular to all intents and purposes." 67

The distinctive feature of Grotius's thought for these commentators is its emphasis on the principle of sociability: "the law of nature was rooted in man's sociable character" and was "in effect the obligation men are under to preserve social peace" and that therefore the "principal condition for a peaceful community is respect for one another's rights."68 Here, again, we see the shift within this strand of justification itself from a descending to an ascending perspective, as Grotius commits what we today recognize to be the naturalistic fallacy by seeking to

64. This approach "asks us to abstract from these deeper or higher beliefs altogether for purposes of political morality" in search of a common basis for peaceful and equitable coexistence that lies "in a protected area, immune from all these warring beliefs" and which "on its own can be shown to be so compelling, that it will command our political allegiance." Taylor, Modes of Secularism, supra n. 61, at 33-34.

65. Id. at 33-34 (noting that Grotius derived the principle pacta sunt servanda from the axioms that humans are both rational and sociable creatures and that, even if God didn't existetiamsi Deus non daretur - these norms would be binding on us).

66. Tuck suggests that Grotius advanced a theory of justice that was "avowedly Aristotelian and accommodated to the assumptions of Protestant political thinkers." Its basic premise was that

"what God has shown to be his will, that is law"-Grotius could not yet disengage

himself from the divine voluntarism inevitably associated with Protestantism. But he explained what God wants in terms of man's innate sociability, to which all further natural laws were to be related, and in that explanation we can see the first indications of what was to be his eventual untheistic theory, with man's sociability becoming the sole premiss.

Tuck, Natural Rights Theories, supra n. 50, at 59-60 (citations omitted).

67. Nussbaum, A Concise History, supra n. 63, at 109.

68. Tuck, Natural Rights Theories, supra n. 50, at 72-73. The claim that sociability necessitates respect for individual rights thus "stressed individuality in the area of rights, but communality in the area of obligation." Tuck sees this as resting on a "psychological implausibility" which would be the dominant point of contention during the next fifty years of debate: i.e., "does a natural rights theory require a strongly individualistic psychology and ethical theory?” Id. at 82. 
derive the meaning of a supposedly universal deontological norm from a comprehensively Christian view of the "human condition" or "human sociability."

In this respect, Grotius was one of the earliest international legal writers to link a strong desire for peace, both between states and individuals, with a theory of rights. This move led to his famous attack on Aristotelian ethics and to the untheistic character of his law of nature which "undeniably limited the point of talking about God in a moral context." ${ }^{69}$ Tuck thus concludes that the De Jure Belli contained in an

embryonic form most of the political theory of the following fifty years, though the developed offspring had to live in a world where the principle of sociability, so important to Grotius, was under fierce attack. $^{70}$

\section{The Exclusionary Origins of the Liberal State}

Our concern then, in the pre-modern period in the wake of the collapse of the unity of Western Christendom, is with a world where the principle of sociability was indeed under "fierce attack"-a world, that is, of emergent European nationalism. Discussion of this early period and its defining normative consequences for later thinking within the liberal tradition is conspicuously absent from contemporary accounts of the origins of religious freedom in both political theory and international law. Thus, modern liberal theorists such as John Rawls appear simply to rely on something close to J.S. Mill's conception of liberal nationalism - the implicit assumption of, and indeed necessity for, the correspondence between peoples or nations and states. ${ }^{71}$

There is, however, a clear tension between a consensual or liberal justification for the nation-state on the one hand, and a communitarian or nationalist (ethno-cultural) justification on the other. As discussed above, modern attempts to combine liberal and nationalist principles derive from the inability of liberal theory to provide a definition of community that can give reasons - consistent with individual freedomfor feeling solidarity with others. ${ }^{72}$ Any assertion of the objectivity of

69. "Given the natural facts about men, the laws of nature followed by (allegedly) strict entailment without any mediating premisses about God's will (though his will might still be an explanation of those natural facts).” Id. at 76-77.

70. Id. at 80 .

71. See John Stuart Mill, Considerations on Representative Government, in Utilitarianism, Liberty, Representative Government 230, 233 (H.B. Acton ed., Adamant Media Corp. 1972) (originally published in 1863).

72. This problem manifests itself in two ways. First, liberalism lacks a theory of citizenship 
the subject of international law itself (i.e., the nation-state) requires consideration of the relationship between not one but two strands of objectivity: one in the form of nationalism viewed as statist and territorial-civic, the other in the form of nationalism viewed as ethnocultural. The former is the secular view of the "state" as the subject of international law premised on the (ascending) free will of individuals. The existence of free and morally autonomous individuals is taken to be an objective fact and the state its logical normative corollary. The difficulty with this view of the state is that without a preexisting "objective" moral order that defines "statehood" or "moral personality" and indicates its normative significance, the concept of the state is empty of content. We thus turn to the second strand, which begins with "situated" subjects—-"peoples"-whose subjectivity is recognized as normative in accordance with a pre-existing "objective" religious or cultural moral order. But now the difficulty is that this moral order looks subjective and thus imposes an unjustifiable constraint on the free will of self-determining individuals. The concept of the nation-state is a combination of these two strands of objective justification which at the same time rely on and deny each other.

The consequence of this argumentative structure is that liberal theories of justice of the kind developed by Rawls in his Law of Peoples depend at some level on background quasi-nationalist ideas of community and citizenship which liberal theory itself is unable to justify. As Jennings makes the point: "the doctrine of self-determination [on] the surface ... seemed reasonable: let the people decide. It was in fact ridiculous because the people cannot decide until somebody decides who are the people."73 As Mill himself correctly imagined, the European nation-state has proved to be the most stable, prevalent and successful form of political community in the modern era. Indeed, some go so far as to suggest that the nation-state is a necessity for a liberal society. ${ }^{74}$ The result has been that by simply assuming a defined

and thus provides "no theory of whom we feel responsibility for and whom we can ignore." The prior existence of a territorial state with a limited citizenry is thus taken for granted as the context in which liberties are to be secured. Second, liberalism lacks an account of "social goods"- those that can only be attained through the cooperation of many individuals. This means that liberal theory can "give reasons for asserting rights, but rarely and with difficulty reasons for individuals to assume duties." Dahbour, Illusion of the Peoples, supra n. 2, at 196.

73. W. Ivor Jennings, The Approach to Self-Government 56 (Cambridge U. Press 1956).

74. Tamir has argued that "liberals have no choice but to presuppose the existence of [communal] ties and 'treat community as prior to justice and fairness in the sense that questions of justice and fairness are regarded as questions of what would be fair or just within a particular political community.'” Yael Tamir, Liberal Nationalism 118 (Princeton U. Press 1993) (quoting Ronald Dworkin, Law's Empire (Harv. U. Press 1986)). For Tamir, the dependence of liberalism 
community of relatively homogenous culturally and religiously similar citizens-however much this may violate its own principles-liberal theory has been able to circumvent such complex issues as membership, minority rights, and immigration. More importantly, however, the mainstream account of the origins of Western nationalism in Enlightenment terms of rights, equality and tolerance has served to obscure the historically exclusionary origins of the Western liberal state. This image has reinforced a false distinction between Western "civic" nationalism on the one hand and non-Western "ethnic" nationalism on the other, the former being seen as a noble invention of the liberal West while the latter describes an ignoble, illiberal characteristic of all Eastern (and more broadly non-Western) Others. ${ }^{75}$

As suggested by Bernard Yack, the tacit identification of the "nation" as the pre-political basis of political community has led over time to the "nationalization of political community."76 Similarly, Anthony Marx has argued that few historical narratives have been as idealized as traditional accounts of the origins of Western nationalism.

As a product of the eighteenth-century revolutions, initial European nationalism was lauded as a liberal form of mass political engagement and allegiance to the secular power of emerging states, consistent with popular rule. Accordingly, its birth was announced with the representation, rights, and toleration of England's constitutional monarchy and its banner the "liberty, equality and fraternity" of the French Revolution against

on nationalism has two components: (1) the assumption of membership in a nation-state that generates a culture of "belonging," and therefore of individuals' obligation to the state, and (2) the limitation of principles of distributive justice to application within a nation-state, without considering whether such principles should be applied beyond the boundaries of that state. Dahbour, Illusion of the Peoples, supra n. 2, at 196.

75. The distinction in the literature on nationalism between territorial-civic and ethnocultural nationalism involves a confusing mix of geographical, sociological, judgmental and normative parameters. For Hans Kohn, the distinction involved two models within Europe (statist, territorial-civic nationalism describing the "advanced" countries of the West such as England, the U.S. and France; ethnocultural nationalism describing the "less advanced" countries in Central and Eastern Europe such as Germany, Italy and Spain-but also Ireland). See Hans Kohn, Nationalism: Its Meaning and History 29-30 (Von Nostrand 1955). There is the further question whether nationalism in either of these two guises is problematic as applied to non-Western (i.e., non-European) societies. For discussion on these issues (which are beyond the scope of this analysis), see Chaim Gans, The Limits of Nationalism 7-38 (Cambridge U. Press 2003).

76. Noting that there were "nations long before nationalism," Yack suggests that

[b]y encouraging us to think of political community as distinct from and prior to the establishment of political authority, the liberal conception of popular sovereignty thus brings our image of political community much closer to national community than it had been in the past.

Bernard Yack, Nationalism, Popular Sovereignty, and the Liberal Democratic State, in The Nation-State in Question 39-40 (T.V. Paul et al. eds., Princeton U. Press 2003) (emphasis added). 
absolutism. Nationalism in the West thus supposedly emerged as a unifying mass sentiment and participation. Specifically, it is usually portrayed as popular cohesion and loyalty to a state or inspiring efforts to build a state that conforms to such solidarity. And such solidarity has been conventionally described and celebrated as tending toward inclusion within a territorial political unit. Though some groups may not have enjoyed equal treatment as members of these nations, such exclusion was often ignored or described as temporary or tangential to an overriding tendency toward inclusion.

Contrary to this inclusive narrative, however, European nationalism emerged at least two centuries before the French and American revolutions in the period of the Wars of Religion, the Peace of Augsburg and the Treaties of Westphalia (which are discussed in more detail in Part III below). Emergent nation-states were consolidated in the sixteenth and seventeenth centuries according to the principle of cuius regio, eius religio - a process characterized by the expulsion of religious minorities, the move towards religious unity, and the spread of linguistic homogeneity. ${ }^{78}$ Efforts to build state power in the absence of popular cohesion and loyalty coincided with differences of faith and religious conflict amid reformation. These religious tensions were harnessed by elites as a basis for state-building and the consolidation of central authority as absolutism.

Early European nation-building was thus a product of both internal and external forces. The peace accords first at Augsburg in 1555 and almost a century later at Westphalia in 1648 were attempts to reduce the effects of the wars of religion between emergent states. At the same time, the civil wars between Catholics and Protestants posed an internal threat to consolidating state authority on account of lack of popular obedience and cohesion. To meet this threat, religion became the obvious vehicle for elites to align widespread mass sentiment with the state. As Marx suggests, "[b]efore confessional identity could be merged or converted into more secular cohesion, religion more immediately reinforced the earlier, institutional process of statebuilding."79 The process worked in both directions: religious identities

77. Anthony W. Marx, Faith in Nation: Exclusionary Origins of Nationalism vii (Oxford U. Press 2003).

78. Of course, it is important not to over generalize or essentialize this point. In Germany, for example, the cuius regio, eius religio principle led to complex processes of consolidation and fragmentation along religious lines.

79. Id. at 36. As Gorski writes, both church and state

constructed new mechanisms of moral regulation (for example, inquisitions, visitations, 
were gradually secularized by states as distinct collective cultural identities that provided the basis for loyalty and obedience while at the same time states and state institutions were shaped by religion. The modern conception of nationalism as a "civic religion" thus finds its origins in the way that confessionalism demarcated community as a form of "social closure." 80

The three countries of Spain, France, and England illustrate this thesis of the centrality of religious intolerance and exclusion to the rise of the European nation-state. The emergence of the Spanish state during the sixteenth century can be traced to the defensive alliance resulting from the wedding of Isabella of Castile and Ferdinand of Aragon in 1469. The consolidation of central authority and the inspiration for national self-determination derived in no small part from the desire to overthrow Moorish rule. ${ }^{81}$ The birth of the Spanish state from the unification of two Crowns did not, however, achieve the unity of two peoples. Spaniards still saw themselves as various nations divided by administrative, linguistic and cultural barriers. ${ }^{82}$ The only form of identification that united Spanish subjects was the Catholic faith which, due to its relative uniformity and avoidance of religious schism, produced less conflict and less secularized identity formation than elsewhere in Europe.

Similarly in France, the "one thing that potentially united the peoples who would come to be known as French was their Catholicism, particularly after the expulsion of the Jews in 1394."83 When Protestantism exploded in France in the mid-sixteenth century, it initially resulted in officially mandated coexistence, when Catherine de'

consistories) and social control (for example, schools, poorhouses, hospitals). Neither purely religious nor strictly political, these institutions were rather res mixtae in which church and state interpenetrated one another to varying degrees. Nonetheless, these institutions could be and eventually were absorbed and appropriated by the state. Confessionalism thus forged a new "infrastructure of power," by which the state began to effectively penetrate social life for the first time.

Philip Gorski, Calvinism and State-Formation in Early Modern Europe, in State/Culture: State Formation after the Cultural Turn 147, 149 (George Steinmetz ed., Cornell U. Press 1999) (n. \& citation omitted).

80. Gorski, Calvinism and State-Formation, supra n. 79, at 170. As Kohn observes, England became the "new Israel" while, building on faith, "France, the devoted daughter of the Catholic Church, graduated to become the mother of her people.” Kohn, Nationalism, supra n. 75, at 11, 16. See further Marx, Faith in Nation, supra n. 77, at 37.

81. Elliott notes that the accommodation of the Moors largely disappeared when "the fall of Constantinople in 1453 revived the crusading enthusiasm of Christendom,” provoking a renewal of efforts at "reconquista" at least of Iberia from the Moors. John Elliott, Imperial Spain, 14691716, at 34, 46-50 (Penguin 1963). See Marx, Faith in Nation, supra n. 77, at 41-44.

82. Elliott, Imperial Spain, supra n. 81, at 126.

83. Marx, Faith in Nation, supra n. 77, at 46. 
Medici realized that the French state was not yet strong enough to prevent compromise. $^{84}$ But the appeasement of the Huguenots brought not peace but calls from the leading Catholic nobles to move against religious toleration to defend Catholicism, even against the King if necessary. The first religious war erupted in March 1562 with the massacre of Huguenot worshippers in Vassy and the accession of Catherine to the superior force of the Catholics. By 1568, bloody civil war between Protestants and Catholics was tearing France apart and, according to one estimate, by 1581 more than 750,000 people had been killed. ${ }^{85}$ In this way, religion and religious fanaticism were used by elites to gain popular support leading to mass violence that threatened to destroy the state itself.

In England, central state power emerged more ambivalently than in Spain or France. The Jews were expelled earlier than in France and Catholicism was unchallenged until the early sixteenth century when the Spanish-controlled pope refused Henry VIII his request for a divorce. Henry broke with Rome and established himself in 1532 as head of the Church of England. ${ }^{86}$ This "conservative revolution from above" thereafter led to the defeat by force of popular movements by Catholic lords and peasants and the seizure of monasteries. The Reformation was halted in England for a period by the short reign of Queen Mary who sought to restore papal obedience. But her efforts produced the opposite effect reinforcing an emerging anti-Catholicism and gathering xenophobia. ${ }^{87}$ Mary's successor, Elizabeth, adopted a more pragmatic policy of toleration, although over time this tilted toward antiCatholicism as she was excommunicated by the pope and Rome supported the invasion of Ireland. This too, however, served only to galvanize England toward greater religious conformity under Protestantism. With the execution of Mary Queen of Scots in 1587, her Catholic rival to the throne, Elizabeth was able to consolidate state power by politicizing the link between Protestantism and English nationalism. ${ }^{88}$

It is important not to essentialize this process and construe the use of religious faith as a sine qua non for European nationalism or hold that

84. See e.g. the Edict of Saint-Germain of 17 January 1562, which suspended and superseded prohibitions and punishments in relation to the Huguenots for "preaching, prayers and other practices of their religion." The French Wars of Religion: Selected Documents 31-32 (David Potter ed., Palgrave Macmillan 1997).

85. Marx, Faith in Nation, supra n. 77, at 56.

86. Id. at 58 .

87. Id. at 62 .

88. Id. at 65 . 
the exclusion of all religious minorities was a consequence of nationbuilding. Indeed, these remain open and contested questions in the literature, with distinctions drawn between the two sides-secular (administrative) and religious_of European state-building in the early modern period. ${ }^{89}$ Nevertheless, in each of these three cases-despite the many different forms of conflict and nationalism that emerged-the one common factor for both mass cohesion and popular loyalty was religion. And, given the divisions and conflicts among the various groups and peoples of Europe, this coalescence could not be done inclusively. Political elites quickly learned that exclusion of a group or groups was necessary to unify a core constituency in order to consolidate the state and create sufficiently stable conditions for governance. Religious exclusion, especially when directed against heretics within, was especially powerful as the basis for nationalism. International conflicts further reinforced early efforts at internal nation-building through exclusion. Spanish Catholics were united against North African Moors, Jews, and foreign Protestants; French Catholics were united against both Huguenots and English Protestants; and English Protestants, in turn, were united against both French and Irish Catholics. ${ }^{90}$ In this way, the politicization of faith and the harnessing of religious identities to consolidate state power converged in waves of exclusionary cohesion.

Once the history of religious exclusions in early European nationalism is acknowledged, it becomes apparent why the traditional account of inclusive "civic" nationalism at the end of the eighteenth century is deeply misleading. ${ }^{91}$ By then, the consolidation of homogenous populations within state boundaries meant that nationalism could be-and was-relatively inclusive and liberal. But this account overlooks the critical earlier processes that made this result possible. The origins of Western nationalism lie then not in a "civic" beginning in

89. These points are especially pertinent to the cosmopolitan history of Catholicism. On the first point, it should be noted that Henry VII engaged in the building of the English administrative state without excessive reliance on religious forces. On the second point, it should further be noted that the expulsion of the Jews from England in the twelfth and thirteenth centuries is generally regarded as being unrelated to the founding of the English nation (and thus may be more coincidental than an essential causal factor upon which nation-building depended.) I am grateful to Jeremy Waldron for discussion on these points.

90. Marx, Faith in Nation, supra n. 77, at 41, 54-55, 66.

91. Referring to the French Revolution, nationalism is described by Kohn as an "inclusive and liberating force" and one that "preserved pluralism ... (and) political liberalism." Hans Kohn, The Idea of Nationalism 3-4 (Macmillan 1944). As regards England, parliamentary rule is described by Haas as establishing "personal liberty with lessons learned about the need for religious toleration.” Ernst B. Haas, Nationalism, Liberalism and Progress: Volume 1, The Rise and Decline of Nationalism 68 (Cornell U. Press 1997). 
an era of liberal democracy, but rather in a series of illiberal exclusions according to perceived differences during the era of absolutism. These exclusions and acts of intolerance provided the foundations on which later liberal and inclusive political orders could be built. ${ }^{92}$

Contemporary conceptions of liberal nationalism and religious toleration are thus the heirs to an earlier liberal tradition premised on group separation (in the form of Westphalian sovereignty) rather than on an inclusive, rational consensus regarding liberal values amongst diverse religious groups. Where pragmatic efforts at tolerance and peaceful coexistence were attempted, prior conflicts and exclusions had generally already solidified authority or popular support. And in most cases, these periods were short-lived as monarchs responded to new internal and external threats by returning to intolerance and religious exclusion in attempts to consolidate weak state power.

The exceptional nature of the rights-based French Revolution thus needs to be understood against this historical background. Two centuries of discrimination and expulsion of non-Catholics had, by 1789, unified the French people. The revolutionaries-now seeing religion and religious exclusion as inextricably tied to the crown and absolutism-reformulated Catholic universalism into a universalism of the Rights of Man and Citizen. The toleration of religion thereby became eclipsed by the complete rejection of religion through adoption of the principles of secular humanism, state secularism and laicité. ${ }^{93}$ Instead of religious exclusions, post-revolutionary France turned to other forms of exclusion and xenophobia to mobilize and strengthen the nation. $^{94}$ The unifying effects of democracy and the rights of citizenship

92. The link between national cohesion and liberal democracy is well-established. Rustow, for example, argues that democratization requires a "single background condition-national unity .... [T] he vast majority of citizens in a democracy-to-be must have no doubt ... as to which political community they belong.... '[T]he people cannot decide [for democracy] until somebody decides who are the people."” Dankwart A. Rustow, Transitions to Democracy: Toward a Dynamic Model, 2 Comp. Pol. 337, 350-351 (1970) (quoting Jennings, Approach to Self-Government, supra n. 73, at 56).

93. As Van Kley observes, "if, as seems plausible, there exists some kind of law of the conservation of the sacred, then the price paid for the desacralization of the remaining symbols of transcendence was an ideological resacralization of a 'regenerated' body of the politic-the nation, the patrie, the people.” Dale K. Van Kley, The Religious Origins of the French Revolution 367 (Yale U. Press 1996). The official separation of religious belief from secular nationalism has been regarded as one of the reasons it took post-revolutionary France so long to be represented by a stable democratic order.

94. In 1794, the Jacobins began a campaign against patois and in favor of the increased use of French to unify the people against linguistic and other differences. See David A. Bell, Lingua Populi, Lingua Dei: Language, Religion, and the Origins of French Revolutionary Nationalism, 100 Am. Hist. Rev. 1403, 1419 (1995). In 1792, émigré nobles were said to be traitors and the next year all foreign-born citizens were stripped of their rights by the Committee on Public Safety. 
thus resulted in a phenomenon that has continued in France to this daythe rejection by the state of any collective claims or any racial or religious categories of distinction or exclusion. ${ }^{95}$

\section{John Locke, Religious Toleration and Westphalian Sovereignty}

But it is in England, in the figure of John Locke, that we see most clearly an early attempt within late seventeenth-century political theory to grapple with the exclusionary and religiously illiberal consequences of the Westphalian settlement. The late seventeenth century was a distinctly fertile period in political philosophy with the likes of Bodin, Spinoza, Hobbes and Locke each seeking to make sense of the tremendous changes occurring as the medieval Christian order collapsed and new forms of political authority asserted themselves. While it is often thought that Locke, in particular, was concerned only with "internal" questions of philosophical natural rights and religious toleration and not with "external” international issues of sovereignty and sovereign legitimacy, this view is mistaken.

Locke clearly saw the connection between and difficulties associated with the external Westphalian "group rights" solution of political entities separated and defined on the basis of religion and internal attempts to formulate natural rights theories seeking to protect the rights of all individuals. ${ }^{96}$ In his famous 1689 A Letter Concerning

Marx, Faith in Nation, supra n. 77, at 172.

95. See generally Rogers Brubaker, Citizenship and Nationhood in France and Germany (Howard U. Press 1992).

96. There is no (or little) mention of Christian teachings or religious toleration, for example, in the Second Treatise. Locke here was grappling with and primarily concerned about the sovereign legitimacy of states (plural) and the consequences of imperialism among other things. Waldron suggests that the Second Treatise is an attempt to "'understand Political Power' and distinguish it from other forms of power." See Jeremy Waldron, God, Locke and Equality: Christian Foundations in Locke's Political Thought 207 (Cambridge U. Press 2002). Thus, Locke's reading of St. Paul's teaching in Romans "does not entail that existing political authority is to be treated as legitimate."

Whether the powers that be are exercising legitimate authority, and consequently

whether we ought to obey them, is something that our Christian faith gives us no particular basis for examining. We must examine it using other resources-like ordinary reason, as encapsulated in good political theory. If reason shows that some de facto ruler is not exercising legitimate authority, then Romans 13 gives the ruler no support. But if reason shows that a de facto ruler is exercising legitimate authority, then the fact that some of his subjects are Christians (while the ruler perhaps is not) does not detract from his authority.

Id. at 196-197. Here we can see the ascending-descending nature of Locke's political theory. It is not that God and theology are irrelevant to the question of political authority (for while governments are chosen and appointed by ordinary consenting people, the authority of people to do so itself derives from God). Rather, as Waldron concludes, "Romans 13 is to be read in the light of Locke's theoretical (indeed his contractarian) argument, rather than the other way 
Toleration, Locke was concerned not only with religious toleration but also with questions of sovereign legitimacy and the basic nature of a political society. In the Letter, he thus sets out definitions of "church" and "commonwealth," noting that churches are groups formed on the basis of free conscience, and that conscience is lonely and singular.

The Commonwealth seems to me to be a Society of Men constituted only for procuring, preserving, and advancing their own Civil Interests. Civil Interests I call Life, Liberty, Health and Indolency of Body; and the possession of outward things, such as Money, Lands, Houses, Furniture, and the like... . Let us now consider what a Church is. A church, then, I take to be a voluntary Society of Men, joining themselves together of their own accord in order to the publick worshipping of God in such a manner as they judge acceptable to Him, and effectual to the Salvation of their Souls. ${ }^{97}$

In establishing the same regime of toleration for all political societies based on the (involuntary) doctrine of cuius regio, eius religio, the Westphalian solution is misconceived. For Locke, political societies should have nothing to do with religion and the impulse to set up religious groups must be distinguished from the impulse to set up sovereign states.

But this picture is more complicated than it first appears. We can see, for example, an apparent contradiction in Locke's definition of churches-but not the commonwealth-as voluntary associations. As Waldron notes,

almost everything Locke says here [in the Letter] about a church, he says about the commonwealth in the Second Treatise. Here he says a church is a free and voluntary society; there he says that political power is established by consent. ${ }^{98}$

This suggests that Locke was perhaps uncertain in the 1680s about how to characterize civil society.

Was it voluntary? Was it in that respect like a church? In that case, what would be the objection to a group of people banding themselves together in an all-purpose association, since they were entitled to band together voluntarily in a state and entitled also to band together voluntarily in a religious association?... In the Letter we are told that the voluntary nature of a church means that

around.” Id. at 196-197.

97. Id. at 212 (citing John Locke, A Letter Concerning Toleration 26, 28 (James Tully ed., Kessinger Publg. 1983)) (alteration in original).

98. See id. at 213. 
people can leave it when they like and take their property with them. Why isn't this equally true of the voluntary nature of civil society? Is it because civil society is not really a voluntary organization at all? Locke's omission of any reference to consent in his definition in the Letter indicates that he was toying with that position. $^{99}$

While Locke was thus clearly opposed to the Westphalian solution of religiously-defined political units, he was at same time unsure about how to deal with the problem that individual freedom-while necessary - was insufficient on its own to provide a coherent rationale for political society. For that, a descending argument would be necessary based not on any specific religion but on a "law of nature" graspable through universal human reason. ${ }^{100}$ I shall return to this point shortly.

Locke's thinking was, in this sense "internal" because it asked how members of any political society should think about these issues. But the point I wish to emphasize is that his theorizing on the individual right of conscience was emerging in a way that was very challenging to the Westphalian system. Waldron notes that Locke expresses distinctly non-Westphalian views in the Letter when he talks about the

danger posed by men who "attribute unto the Faithful, the Religious and the Orthodox, that is, in plain terms, unto themselves, any peculiar Privilege of Power above other Mortals, in Civil Concernments." He mentions, for example, the rule that "Faith is not to be kept with Hereticks," or the principles that "Dominion is founded in Grace" and that "Kings excommunicated forfeit their Crowns and Kingdoms." These, Locke says, have no right to be tolerated by the magistrate. ${ }^{101}$

His famous theory of the "mutual Toleration of Christians" thus flows from such premises on the basis that the

Toleration of those who differ from others in Matters of Religion is so agreeable to the Gospel of Jesus Christ... that it seems monstrous for Men to be so blind, as not to perceive the Necessity

99. Id. at 214

100. The starting point in Locke's conception of political authority is ascension from individual consent. The descending part is to be found in his natural law theory which, Locke himself would later say in The Reasonableness of Christianity has nowhere been better expounded than in Christianity. See id. at 207. For Waldron's analysis of the apparent dissonance between the "lack of Gospel-based argument" in the Second Treatise and the pessimism in the Reasonableness about a "systematic and compelling exposition of the natural law, even in the post-Christian era, except on the basis of the teachings of Christ.” See id. at 207-216.

101. Id. at 221 (citing Locke, Letter, supra n. 97, at 50). 
and Advantage of it in, so clear a Light. ${ }^{102}$

Nevertheless, it is commonly said that Locke's broad argument for religious toleration, while explicitly including Protestant factions, implicitly excluded the one group most in need of tolerance-Catholics. Marx, for example, refers to Locke's "selective version" of toleration as follows:

The only discord to be ended, covered over with tolerance and forgotten, was among Protestant factions unified at least against Catholicism as a nation. That this selective form of toleration would be hailed as purely liberal principle is incredible enough. That this sleight of hand would be celebrated on face value attests to England's own willingness to forget and suggests that Locke's successors were less conscious of the limits of liberalism than was he. ${ }^{103}$

A closer reading of the Letter reveals, however, that the limits of toleration for Locke were not to be drawn on the basis of any particular faith, but rather only on account of the combination of faith with allegiance to a foreign power. Indeed, the only references to Roman Catholicism and "papists" in the Letter are included to make the argument for toleration. ${ }^{104}$

By contrast, a passage often referred to as evidencing Locke's intention to exclude Catholics reads as follows:

That Church can have no right to be tolerated by the Magistrate which is constituted upon such a bottom, that all those who enter into it, do thereby, ipso facto, deliver themselves up to the Protection and Service of another Prince. For by this means the Magistrate would give way to the settling of a foreign jurisdiction

102. Locke, Letter, supra n. 97, at 25.

103. Marx, Faith in Nation, supra n. 77, at 179. For discussion on Locke's views of toleration among Protestants, see Susan Mendus \& John Horton, Locke and Toleration, in John Locke: A Letter Concerning Toleration in Focus 1 (John Horton \& Susan Mendus eds., Routledge 1991).

104. In relation to Roman Catholics, Locke states that

the Magistrate ought not to forbid the Preaching or Professing of Any Speculative Opinions in any Church because they have no manner of relation to the Civil Rights of the Subjects. If a Roman Catholick believe that to be really the Body of Christ, which another man calls Bread, he does no injury thereby to his Neighbor.

Locke, Letter, supra n. 97, at 46. As Waldron observes, when "Locke sums up his position on toleration at the end of the Letter - "The Sum of all we drive at is, That every Man may enjoy the same Rights that are granted to others"-we find that Rome is included effortlessly along with Geneva." See Waldron, God, Locke and Equality, supra n. 96, at 218-220. The same is true in the later Letters. Throughout, Locke insists that "neither pagan nor Mahometan, nor Jew, ought to be excluded from the civil rights of the commonwealth because of his religion." Locke, Letter, supra n. 97, at 56 . 
in his own Country. ${ }^{105}$

Locke thus appears to advance three grounds for the exclusion of Catholics. First, as the first passage concerning not keeping faith with heretics suggests, ${ }^{106}$ certain Roman Catholic doctrines bestow legal privileges on Catholics over and above the civil rights of other citizens which is a challenge to a nation-state. Second, such doctrines (as opposed to Catholics themselves or Catholicism as a faith) are a "secret Evil," posing a threat to the state on account of the secretive nature of Roman Catholic political practice. ${ }^{107}$ And third, as we have seen, it is not possible in some cases to disaggregate Catholicism as a faith from Catholic doctrines "absolutely destructive of the society wherein they live" because they are premised on Vaticanism and loyalty to a foreign power.

These arguments regarding toleration of Catholics (and Muslims, for that matter) can be read in two ways. For Waldron, they provide evidence that in Locke's thought, certain political doctrines should not be tolerated. To the extent that Catholicism is not politically subversive, it should be viewed as "one tolerable religion among others in a multifaith society." "108 But again, the picture may be more complicated as we view Locke's attempt to grapple with the myriad implications of the Westphalian settlement for the relationship between religion and the state. Notice, for example, how in the passage above regarding Muslims, Locke both refers to a "Christian Magistrate" and depicts as subjective the way in which the Mufti of Constantinople "frames the feigned Oracles of that Religion according to his Pleasure." In both instances, there are distinctly Protestant assumptions at work.

For Locke, Catholicism and Islam and the doctrines which flow from them, as mediated by the human authority of the Pope and the Mufti of Constantinople, are suspect because they proceed from wholly descending (and thus subjective) premises. But while the Magistrate

105. Locke, Letter, supra n. 97, at 50. In another passage on the same page, Locke refers to Muslims in the same vein:

It is ridiculous for anyone to profess himself to be a Mahumetan only in his Religion, but in every thing else a faithful Subject to a Christian Magistrate, whilst at the same time he acknowledges himself bound to yield blind obedience to the Mufti of Constantinople; who himself is intirely obedient to the Ottoman Emperor, and frames the feigned Oracles of that Religion according to his pleasure.

106. See supra text accompanying n. 101. Waldron suggests, however, that Locke is careful to "characterize these views in general terms, so that their link with Rome or with any particular religious sect is understood as contingent rather than necessary." Waldron, God, Locke and Equality, supra n. 96, at 222.

107. Locke, Letter, supra n. 97, at 49.

108. Waldron, God, Locke and Equality, supra n. 96, at 223. 
may be "Christian," this does not appear to impinge on his ability objectively to interpret either the Commonwealth's (neutral) civil laws or the (universal) Natural Law. My point is that while Locke's political theory proceeds from a characteristically liberal (ascending) premise of individual freedom, he cannot thereby avoid the need to formulate certain "objective" (descending) arguments derived variously from Natural Law or Christian theology, which today we would recognize as subjective and thus vulnerable to exactly the same sorts of criticisms Locke leveled against Roman Catholicism and Islam. ${ }^{109}$

This point is further supported by Locke's well-known refusal to tolerate atheists. While we cannot pursue the question in detail here, we should at least take note of Waldron's thesis that "it may be impossible [for Locke] to articulate certain important egalitarian commitments without appealing to what one takes to be their religious grounds."110 For Locke, the existence of God (and, indeed, the specific teachings of Jesus Christ) ${ }^{111}$ were indispensable to his theory of human equality. On this basis

Those are not to be tolerated who deny the Being of a God. Promises, Covenants, and Oaths, which are the Bonds of Humane Society, can have no hold upon an Atheist. The taking away of God, tho but even in thought, dissolves all. ${ }^{112}$

The very foundations of social order rest, for Locke, on the fear of God. Furthermore, divine sanctions are necessary for both morality and natural law and "awareness of the existence of God also underpins people's ability to take seriously the idea of objective right answers to

109. For example, in the first reason above for excluding Catholics on the basis of doctrines enshrining Roman Catholic privileges, Locke appears to assume that there must be "one law for all, no exceptions" and that law must be "secular." Consistent with rationalist Enlightenment premises, the idea of minority rights or the ones of religiously-based autonomy regimes of the kind we find existing today in India, for example, are not considered by Locke. Religion involves individual "conscience" and differences of belief between individuals, even between a Catholic and a Muslim, do "no injury thereby to his Neighbor." See supra n. 104. The separation between the religious and secular spheres has already been made in Locke's thought both within the (Protestant) individual and the (liberal) state. It does not occur to him that this separation may itself be subjective and that there may be other equally reasonable and rational ways of understanding that relationship.

110. Waldron, God, Locke and Equality, supra n. 96, at 237.

111. Waldron argues that for Locke, it was an open question about the extent to which nonChristian or non-monotheistic faiths may provide a basis (through some form of Rawlsian overlapping consensus) for a theory of natural rights and human equality. Certainly, while Locke's main concern was with theism per se (i.e., belief in God), his work drew virtually exclusively on Judeo-Christian sources. See id. at 230-231.

112. Locke, Letter, supra n. 97, at 51. 
the moral questions to which their actions give rise."113 The menace posed by atheists is that they cannot grasp either the basis of the inalienability of human rights or the kind of respect that is "due to each one of God's human creatures as such" under a strong theory of natural rights and human equality.

If today, drawing from Locke, we regard Westphalia as marking the birth of free and equal "secular" subjects-whether states or individuals - then at least this conception must be qualified to include comprehensively religious, and specifically Christian, foundations for Locke's account of liberal equality. While later liberal theorists such as Rawls have sought to advance philosophically secular theories of public reason and autonomous moral personality independent of comprehensive, and thus subjective and controversial, religious views, God remained an indispensable transcendent premise in Locke's late seventeenth-century thinking both about sovereignty in the case of states and natural rights in the case of individuals.

In this respect, Locke should be read as thinking not only about internal questions, but also as grappling with "external" international legal dilemmas about the meaning of statehood and how sovereignty is to be defined. Like the generations of liberal internationalists which would follow him, Locke thus required a non-sectarian but nevertheless deontological (descending) argument based on a pre-existing "objective" moral order that could define "statehood" and indicate its normative significance. While it was necessary, the combination of the (ascending) premise of free individuals and (descending) notion of a neutral state based on their consent was on its own insufficient to provide a coherent justification of state sovereignty. Locke required a theological conception of natural law not related to any particular religion but ascertainable through ordinary human reason. While the existence of such a universal natural law was both obvious and rationally discoverable, to later theorists Locke's normative natural law positions have appeared both subjective in the form of European prejudice and apologist in justifying imperial imposition on other ways of life. ${ }^{114}$

113. Waldron, God, Locke and Equality, supra n. 96, at 225.

114. This is not to say, however, that Locke did not turn his "universalist critique against European customs, and conjectures" as well. The point is not that "Locke reflexively invest[ed] the practices of his own culture with an aura of moral universalism" or that he was "complicit in a deliberate attempt to dehumanize the peoples and practices that the colonists faced in the new world.” Id. at 168. Rather, the point is that Locke's Natural Law and the doctrines he derived from it no longer appear to us, three centuries later, as either especially "natural," "objective," or "universal." 
Even conceding this, however, there can be no doubt that Locke's natural law justification for sovereignty did provide an "objective" norm requiring something close to universal respect for different ways of life (qualified by a natural law version of Mill's harm principle). In this respect, Waldron draws our attention to a quite remarkable passage in the Letter where Locke says that

[n]ot even [native] Americans, subjected unto a Christian Prince, are to be punished either in Body or Goods, for not imbracing our Faith and Worship. If they are perswaded that they please God in observing the Rites of their own country... they are to be left unto God and themselves. ${ }^{115}$

Accordingly, says Locke,

[l]et us trace this matter to the bottom. ... An inconsiderable and weak number of Christians, destitute of every thing, arrive in a Pagan Country: These Foreigners beseech the Inhabitants, by the bowels of Humanity, that they would succour them with the necessaries of life: Those necessaries are given them; Habitations are granted; and they all joyn together, and grow up into one Body of People. The Christian Religion by this means takes root in the Countrey, and spreads itself; but does not suddenly grow the strongest. While things are in this condition, Peace, Friendship, Faith and equal Justice, are preserved amongst them. At length the Magistrate becomes a Christian, and by that means their Party becomes the most powerful. Then immediately all Compacts are to be broken, all Civil Rights to be violated, that Idolatry may be extirpated: And unless these innocent Pagans, strict Observers of the Rules of Equity and the Law of Nature, and no ways offending against the Laws of the Society, I say unless they will forsake their ancient Religion, and embrace a new and strange one, they are to be turned out of the Lands and Possessions of their Forefathers, and perhaps deprived of Life itself. Then at last it appears what Zeal for the Church, joined with the desire of Dominion, is capable to produce; and how easily the pretence of Religion, and of the care of Souls, serves for a Cloak to Covetousness, Rapine, and Ambition. ${ }^{116}$

It was thus clear for Locke that human equality and religious toleration, even when transposed to the international context of encounters with foreign peoples, rested on the separation of religious and political forms of power and sovereign legitimacy. The idea that Zeal-not for the

115. Locke, Letter, supra n. 97, at 43 (cited in Waldron, God, Locke and Equality, supra n. 96, at 167).

116. Id. 
Church-but for Reason itself could serve "for a Cloak to Covetousness, Rapine, and Ambition” must not have appeared possible to Locke.

\section{E. From the History of Liberal States to Modern Liberalism}

In this concluding section, I discuss the broad implications of sections A-D above for our modern understanding of the right to freedom of religion and belief. In particular, I argue that the early modern history of "liberal" states, especially when viewed alongside subsequent attempts by theorists such as Locke to deal with the exclusionary and religiously illiberal nature of their origins, raises a number of challenging implications for the modern liberal tradition. In each case, liberalism was founded on-perhaps even made possible by-illiberalism and the connection to a particular political community demarcated initially by faith. Before democracy and liberal rights could be declared and consolidated, "boundedness" was necessary to create the solidarity and unity of the nation. Once established, however, that boundedness was gradually forgotten and transposed into a more secular, "objective” Natural Law, creating the illusion of a commitment to inclusive universal values and toleration of diverse ways of life. ${ }^{117}$ As Waldron concludes in his analysis of Locke's political thought,

[i]t may seem to us now that we can make do with a purely secular notion of human equality; but as a matter of ethical history, that notion has been shaped and fashioned on the basis of religion. That is where all the hard work was done. ${ }^{118}$

In a similar vein, Joseph Raz has argued that this history in part explains the ambivalence of the liberal tradition towards the role and justification of fundamental rights. ${ }^{119}$ Claims of the role of rights in securing individual freedom were advanced against such a natural social background of collective goods that their "contribution to securing the very ends which were supposed to be served by the rights was obscured,

117. Marx refers to this as the "ugly secret" at the heart of liberalism.

Founded on this basis [of exclusions], liberal democracy would then eventually serve as cover, with gradual enfranchisement hiding past exclusions and obfuscating that at the heart of liberalism is an illiberal determination of who is a member of the incorporated community and who is not.

Marx, Faith in Nation, supra n. 77, at 200.

118. Waldron, God, Locke and Equality, supra n. 96, at 242.

119. J.S. Mill, for example, did not assign rights a foundational role in his moral or political theory. In the case of those liberal philosophers who did, such as Locke, they were "commonly pressed into service in the interests of an individualistic moral outlook." Joseph Raz, The Morality of Freedom 250-251 (Oxford U. Press 1986). 
and all too often went unnoticed." ${ }^{120}$ Raz notes, in particular, that in seeking to understand the history of liberalism, it is of great importance to realize that the right to religious freedom-which is so intimately tied to the early growth of liberal ideals - was "bound up with the existence of a public culture in which religion was a social institution."121

Religious toleration may have been defended in the name of individual conscience, but it served communal peace. More to my point, inasmuch as religion is and was a social institution embracing a community, its practices, rituals and common worship, the right to free religious worship, which stood at the cradle of liberalism, is in practice a right of communities to pursue their style of life or aspects of it, as well as a right of individuals to belong to respected communities. Thus while religious freedom was usually conceived of in terms of the interest of individuals, that interest and the ability to serve it rested in practice on the secure existence of a public good: the existence of religious communities within which people pursued the freedom that the right guaranteed them. Without the public good the right would not have had the significance it did have. Furthermore, the existence of the right to religious freedom served in fact to protect the public good. I venture to surmise that but for that it would not have acquired the importance that it did. ${ }^{122}$

The collective dimensions of individual rights - their role in fostering a public culture enabling people to value and take pride in their identity as members of distinct groups-is thus a critical factor in the story of religious freedom. This obliges us to question Enlightenment views of individual freedom as being in some essential sense opposed to or independent of collective goods such as religion, culture and tradition. Rather we need to ask, with Raz, whether personal freedom and autonomy may not better be conceived as either elements in the protection of, or valuable because they depend on and serve, certain collective goods. ${ }^{123}$

In this vein, let me now try to draw together the discussion in the preceding sections and suggest its implications for the structure of religious freedom in international law. If the starting assumption in

120. Id. at 251 .

121. Id. at 252 .

122. Id. at 251 .

123. Id. at 254. As Raz observes, this is not to say that fundamental rights are not in competition with other collective goods, or that they do not conflict with other rights. On the contrary, the point is merely that "there is no general rule giving either rights or collective goods priority in cases of conflict.” Id. at 255. 
liberal theory is that peoples with their own religious and cultural nomoi are prior to the state, then the substantive meaning and function of the state itself can only be determined by abstracting in an ascending way from the particular cultural and religious values and beliefs of these groups in the search for an objectively-agreed "ethical" means of coexistence. The difficulty, as we have seen, is that an unforced consensus on norms of coexistence consistent with the comprehensive views of all such groups is unlikely in any culturally and religiously diverse state. We require then a rationally undeniable argument that is not contingent on consensus. Hence the turn to the "statist" or "territorial-civic" strand of justification which posits the state as neutral, independent from and superior to any and all national cultural and religious groups. ${ }^{124}$ In order to maintain its objectivity and neutrality, however, the state now imagines a public-private divide whereby religious and cultural traditions are legally disestablished and privatized. But as we have seen, this conception leaves the statist norm empty of material meaning. How then is the state to fulfill its imperial world maintaining role both internally in resolving moral conflicts between its citizens and externally in seeking convergence on ethical norms of coexistence with other "sovereign” (i.e., "equally free”) states?

This dilemma engenders two distinct forms of justification, each requiring a different mode of recourse to comprehensive values, the former by a descending moral and the latter by an ascending ethical argument. The first form concerns what Michael Walzer has termed the "constitution of the self" - the identity of the statist nomos-and is an "internal" question of communitarian morality requiring reliance, at some level of argument, on particular paideic value. ${ }^{125}$ But this is precisely the problem liberal theory had hoped to avoid. The second form concerns the "connection of constituted selves"- the relationship between formally equal and independent statist nomoi-and is an "external" question of political ethics requiring the search for an overlapping consensus on the basis of different paideic views of the good. But this also returns us, now in the context of an inter-national as opposed to an intra-national nomos, to where we began. Each context of justification contains both paideic and imperial modes within it and each denies and relies on the other in an endlessly intersubjective series of transformative oscillations.

124. On this distinction, see supra $\mathrm{n}$. 71 to 77 and accompanying text.

125. See Michael Walzer, The Communitarian Critique of Liberalism, 18 Pol. Theory 6, 21 (1990). 
Let me again emphasize that this is not how the history of Westphalia is ordinarily read. Indeed, it is a quite unfamiliar way of thinking about the Westphalian moment which today is understand as ushering in the modern "liberal" international legal system of "secular" sovereign states. On this mainstream view, the unified religious nomos of Western Christianity premised on the "sacred/sin" distinction became eclipsed by a new pluralist secular nomos premised on a distinction between separate but equal "secular" and "religious" domains. Again, following Walzer, this notion of separate but equal spheres has two dimensions: one internal (i.e., in the constitution of the individual subject) and the other external (i.e., in the relations between individual subjects). In the shift, the sacred (wholly descending) notion of the divine became transformed into the secular (ascending-descending) notion of individual moral personality. ${ }^{126}$ And like the former profanity of $\sin$, the religious in this way became the "sign of the inalienably different-which must be puzzled over and suppressed and tolerated and denied and accepted and outgrown." ${ }^{127}$ Religion henceforth was said to be "private" - the domain of irrationality and charismatic authoritywhile the law was "public" - the realm of reason and universal authority. As David Kennedy puts it, religion is "what we had before we had law," and accordingly, "[i]nternational law understands its birth as a flooding forth from the darkness of religious strife, antidote to the passions of faith, on guard against their re-emergence as ideology."128

It is this almost unconscious historical narrative that I have endeavored to revisit and reconsider. I have suggested that the Grotian moment should be read as marking two conceptual transformations. The first change, at the normative level, occurs as a sacred (wholly descending) argument is transformed into a secular (ascending-

126. This shift is well-captured by Waldron, who notes the analogy between "John Locke on God" and "John Rawls on moral personality." Waldron suggests that Rawls's conception in his political liberalism of the human person as a free agent with certain moral powers "has to be able to do by itself ... all the work for equality that is done, for Locke, by the notion of our status in the eyes of God.” Waldron, God, Locke and Equality, supra n. 96, at 239-240. Thus:

For Locke, the religious foundation is indispensable: we have seen it do important work

in political theory, as premise and as a constraint. For Rawls, the moral personality stuff

is a similarly load-bearing part of the theoretical structure, and similarly indispensable. Id. at 240 .

In proceeding to note that Rawls's theory does not necessarily fail by relying on some comprehensive conception of moral personality, Waldron argues that the "overlapping consensus that defines his political liberalism does have indispensable content, and some of that content is controversial.” Id.

127. David Kennedy, Losing Faith in the Secular: Law, Religion and the Culture of International Governance, in Religion and International Law, supra n. 54, at 309, 313.

128. See id. at 313. 
descending) argument that at once denies and requires the comprehensive meaning and values of the prior order. The second change, at the factual level, occurs as the comprehensively Christian subject is transformed into the secular liberal subject for whom faith is private and reason public and for whom a doctrine of fundamental rights demarcates the divide between the two. In both transformations, postWestphalian international law recognized and sought to contain the crisis of unitary authority that arises in any comprehensively religious legal order. Ultimately, however, the law has been forced to leave the question of authority open and represent itself as universal only by remaining empty of material meaning. This result is, of course, less obvious at the domestic level where authority is vested in a purportedly "neutral" Leviathan which must, when faced with conflicts of value, ultimately adopt and enforce controversial conceptions of the good.

\section{Religious FreEdom In A WeStPHALIAN WORLD OF SOVEREIGN STATES}

Having considered the nature and scope of religious liberty in the early modern period, let us now turn to my second general argument concerning the relationship between religious freedom and the Westphalian notion of the "sovereignty" of states. As we have already seen, it is an article of faith among modern international lawyers that the 1648 Treaties of Westphalia marked the birth of the modern state system - the emergence of the "secularized society of States which has characterized international relations since the mid-seventeenth century." 129 The reality, of course, is more complicated than this proposition suggests. What is clear is that religion-the history of Christianity, in particular-has been the dominant force in the formation and shaping of the international legal system. Indeed, I wish to argue that the idea of state sovereignty itself is a product of historical struggles that have occurred both within Christianity and between Christian States and (non-Christian) peoples following different religions. ${ }^{130}$ In light of this history, it is more accurate to regard the Peace of Westphalia as a social contract or modus vivendi of peoples who, when faced with the alternative of unending religious civil war, consolidated a society of

129. Evans, Religious Liberty, supra n. 53, at 42. See also Antonio Cassese, International Law in a Divided World 37-38 (Oxford U. Press 1986).

130. Note, e.g., Ago who has argued that the origins of the modern international legal system should be traced back to the three empires of Charlemagne, Byzantium, and the Ottomans - each adopting a different religion and each interacting with the others. Roberto Ago, Pluralism and the Origins of the International Community, 3 Italian Y.B. of Intl. L. 3 (1977). 
Christian States whose sovereignty was based on the reciprocallyrecognized principle of cuius regio, eius religio. ${ }^{131}$ Westphalia, in other words, marked the recognition in international law of the religious freedom not of the individual but of the State. State sovereignty was in effect the early liberal "group rights" solution to the problem of religious and cultural pluralism. This is a critical point for our contemporary understanding of the origins and evolution of political liberalism. ${ }^{132}$

\section{A. From Ius Gentium to Ius Inter Gentes}

We need to go back almost a century, however, to the gradual spread of the Protestant Reformation in the German territories to appreciate the full significance of the Treaties of Westphalia. Unable to eradicate the Lutheran "heresy," the Holy Roman Empire entered into the Religious Peace of Augsburg in 1555, the cornerstone of which was the principle of cuius regio, eius religio. ${ }^{133}$ This secured to the Lutheran princes and rulers full equality with the Catholic princes, and permitted the lay princes to determine the religion of the inhabitants within their respective territories. ${ }^{134}$ While at the time, it was regarded as a modus

131. For Koskenniemi, the order which was instituted between sovereigns in the Peace of Westphalia marks "the transition from a Christian view of the world as an objective hierarchy of normative meaning to a historically relative consensus." This was manifested in three ways:

It was recognized that even the possible existence of universal values was not a sufficient casus belli; secondly, the formal equality of the European sovereigns guaranteed the legitimacy of the internal policies of these same sovereigns; thirdly, the arrangement proceduralized inter-sovereign relations and allowed national interest as legitimate reason of war if only proper formalities were followed. At Westphalia, the sovereigns made a social contract. This involved accepting an ascending and a descending argument about international legitimacy: order was to emerge from the sovereigns themselves and the right of sovereigns to constitute an order of their liking was assumed as "inherent."

Koskenniemi, Apology to Utopia, supra n. 15, at 72-73.

132. Note that Rawls, too, locates the

historical origin of political liberalism (and of liberalism more generally) ... [in] the Reformation and its aftermath, with the long controversies over religious toleration in the sixteenth and seventeenth centuries. Something like the modern understanding of liberty of conscience and freedom of thought began then. As Hegel saw, pluralism made religious liberty possible, certainly not Luther's and Calvin's intention.

John Rawls, Political Liberalism xxiv (Colum. U. Press 1993).

133. The feudal structure of the Empire comprised two classes of territories. The first encompassed approximately eighty territories ruled directly by their own princes but through whom the emperor "mediated" his authority. Of these, around fifty were ecclesiastical territories and the rest were secular. The other class comprised either "free" imperial cities or cities which were the "private possession of a large number of lesser knights of the Empire, who held their often quite small possession directly from the emperor, whose authority in both these instances was 'immediate.” Evans, Religious Liberty, supra n. 53, at 46.

134. Nussbaum, A Concise History, supra n. 63, at 61. The Peace explicitly recognized the freedom of the Lutheran Church to self-government over internal matters (Art. 20); and this 
vivendi until some "ultimate transaction of religion" occurred, the Peace in fact signaled the collapse of the notion of empire based on a common religion. $^{135}$ Again, it must be emphasized, however, that this fell far short of the acceptance of religious freedom throughout the Empire. Cities and lay princes could only choose between Roman Catholicism and the Lutheran Confession as the single religion within their territories and ecclesiastical principalities were subjected to the so-called "Ecclesiastical Reservation." 136 As Evans notes, the "only concession to individual conscience made by the Peace was that it granted Catholic or Lutheran subjects the right to move (the ius emigrandi) to a territory where the religion of the prince was more congenial." ${ }^{\text {"137 }}$

Over the next fifty years, the struggle between Catholic and Protestant, Lutheran and Calvinist states continued throughout Central and Northern Europe until the Protestant seizure of Bohemia in 1618 precipitated the onset of the Thirty Years War. After decades of bloodshed which drew in all of the main European powers, the much weakened and demoralized imperial forces finally concluded the Westphalia Treaties in 1648 with their opponents at Münster and Osnabrück. ${ }^{138}$ Nussbaum suggests that the Peace had three significant features: (1) the members of the Holy Roman Empire (then more than three hundred) were "lifted to an international status approximating sovereignty though the old term Landeshoheit (territorial supremacy) was preserved;" (2) extending well beyond the Peace of Augsburg, Westphalia "brought forth the first international recognition of Protestantism —or, more precisely, of Lutheranism and Calvinism;” and (3) the Peace established a collective sanction mechanism which is "historically important as the first attempt at international organization for the maintenance of peace." ${ }^{3139}$

The second of these features requires further explanation. While confirming the basic tenets of the Peace of Augsburg, the Treaties of

surrender of ecclesiastical jurisdiction ensured that in the free and imperial cities of the Empire, both religions were permitted co-existence. For the text of the Peace, see Evans, Religious Liberty, supra n. 53, at 46.

135. See Evans, Religious Liberty, supra n. 53, at 47.

136. Under Art. 18 of the Peace, Ecclesiastical territories that had been won over to Lutheranism were compelled to return to Roman Catholicism although, by the Declaratio Ferdinandea, the emperor agreed to allow practicing Lutherans in these territories to continue in their faith. Id. at 47-48.

137. Id. at 48.

138. Treaty of Peace between France and the Empire, signed at Münster 14 (24) Oct. 1648 (1 CTS 271); Treaty of Peace between Sweden and the Empire, signed at Osnabrück 14 (24) Oct. 1648 (1 CTS 119).

139. Nussbaum, A Concise History, supra n. 63, at 115-117. 
Westphalia extended and refined this earlier framework in several respects. First, the Reformed (Calvinist) Church was now internationally recognized as a confession alongside Lutheranism and Catholicism. Second, the cuius regio, eius religio principle was now extended beyond the lay principalities to the free and imperial cities. ${ }^{140}$ And third, certain limited rights of individual freedom of conscience were recognized. ${ }^{141}$

The cumulative effect of these treaties was a completely changed relationship between the imperial crown and the constituent territories of the Empire, the German princes now having a form of territorial sovereignty that amounted to independence in both temporal and spiritual matters. Similarly, treaty practice following Westphalia was motivated more by the desire to eliminate possible causes of conflict than by any desire to "promote religious liberty or tolerance as an end in itself."142 In addition to agreeing to fulfill their own obligations, states also assumed obligations as guarantors of specific elements of the various settlements, a practice culminating in the Congress of Vienna of 1815 and in the multilateral system of the "Concert of Europe."143 While to the papacy the division of Christendom had been a disaster, ${ }^{144}$ the notion of empire unified by the universal Catholic faith was now

140. This affected contentious issues regarding the ownership of religious property and the enjoyment of religious freedoms. As Evans notes, the treaty "sought to enforce the religious status quo as of [1624], and where religions had co-existed the continuation of both was affirmed.” Evans, Religious Liberty, supra n. 53, at 52.

141. According to the terms of Article V, §§ 28-30:

Catholics and Lutherans who were not entitled to the public or private exercise of their religion in 1624 because of their being in a territory of a different religious allegiance (in which it was confirmed by the treaty) were to be "patiently suffered and tolerated, without any hindrance or impediment” in both public and private worship, and were also to be able to send their children to foreign schools or have private tutors, but only for a short period. The lord of the territory was entitled to require a subject of the different faith to move elsewhere after a period of five years. Id. at 52-53.

142. The aim of most post-Westphalian treaty practice was to preserve the status quo of religious practice in the face of any territorial changes between states or dynastic ambitions. When territory was ceded by one sovereign to another, subjects would therefore be allowed to continue in the private exercise of their religious beliefs or to emigrate. Id. at 55-57 (noting, however, that the "spirit of the Enlightenment engendered a liberalization of internal regulation of religious affairs throughout Europe").

143. Thus, Article IX of the Polish-Prussian Treaty of Warsaw (1773) provided that the King of Prussia shall "guarantee all and such constitutions that shall be drawn up ... in the Diet... both upon the structure of the free government... and on the pacification and the status of the Uniate religion and of the Protestants, Calvinist and Lutheran.” Id. at 57.

144. In Zelo domus Dei, Pope Innocent X denounced the religious aspects of the Treaties of Westphalia as "null, void, invalid, inequitable, unjust, condemned, reprobated, frivolous, of no force or effect.” Nussbaum, A Concise History, supra n. 63, at 116. 
officially dead.

\section{B. Christian States and Non-Christian Peoples}

Quite apart from these developments between the European states in the wake of Westphalia, the other significant aspect of the emergence of religious freedom in international law concerns encounters between Christian states and other non-Christian peoples. As we have seen, one of the main questions which Grotius and his followers sought to address was whether, and on what basis, it was possible for Christian sovereigns to enter into binding treaties with non-Christian powers. Here the history of Islam and the treaty practice between the European powers and the Ottoman Empire has had a significant impact on the evolution of freedom of religion in international law.

Like Christianity, Islam has historically been an aggressively proselytizing universalist religion. But scholars of Islam have often argued that, as compared with Christianity during the same period, the Ottoman Empire encompassed various "liberal" forms of religious toleration, in particular towards religious minorities considered to be "peoples of the book." ${ }^{145}$ This toleration was effected through the Ottoman millet system. For over five centuries between 1456 and World War I, three non-Muslim minorities were officially recognized by the Ottoman Turks as self-governing communities or "millets" with their own legal codes and courts-the Greek Orthodox, the Armenian Orthodox, and the Jews. The legal traditions and practices of each community were respected, including the freedom to practice their religion, although relations between the millets and the ruling Muslims were strictly regulated. ${ }^{146}$ This conception of toleration of religious minorities was therefore far from "liberal" in the modern sense-it did not tolerate individual dissent or freedom of choice within its constituent communities, although the extent to which the various millets sought to enforce religious orthodoxy varied. Kymlicka suggests that the millet system was a "deeply conservative, theocratic, and patriarchal society, antithetical to the ideals of personal liberty endorsed by liberals from Locke to Kant to Mill." ${ }^{\text {"147 }}$ He notes, however, that over the five-

145. Evans, Religious Liberty, supra n. 53, at 59.

146. While collective freedom of worship was protected, "non-Muslims could not proselytize, they could build new churches only under license, and they were required to wear distinctive dress so they could be recognized. There were limits on intermarriage, and they had to pay special taxes in lieu of military service." Will Kymlicka, Two Models of Pluralism and Tolerance, in Toleration: An Elusive Virtue 81, 83 (David Heyd ed., Princeton U. Press 1996).

147. Id. at 83-84. 
hundred-year history of the millets there were periods when "liberal reformers within each community pushed for constitutional restrictions on the power of the millet's leaders." ${ }^{148}$ This led, in the late nineteenth century, to some millets' adoption of liberal constitutions. In general, however, the Ottoman conception of tolerance meant the "willingness of a dominant religion to coexist with others" and did not include the "separate principle of individual freedom of conscience."149

The millet system reveals the contrasting approaches of the Holy Roman and Ottoman empires to the question of religious toleration. The intolerance of the papacy and insistence on an empire unified by the universal faith of Roman Catholicism led inexorably to the Wars of Religion and the eventual modus vivendi at Westphalia. The territorial "sovereignty" of the newly emergent states was thus determined by the relationship between various national groups and their religious confession (cuius regio, eius religio). The legal "sovereignty" of these states, however, was no longer determined by a solely descending interpretation of divine law, but by an ascending-descending combination of reciprocal treaty obligations and natural rights. As we have seen, the descending strand of justification was derived interchangeably from faith or right reason (or both) with different writers asserting different competences, sets of rights and legitimate spheres of action from the State-as-Individual in a State of Nature analogy. "Sovereignty" in this sense was a bundle of contested assumptions concerning the proper relation of autonomous agents in a state of nature, whether encompassing the Hobbesian natural right to self-preservation or extending to Pufendorfian conceptions of rich natural sociability. ${ }^{150}$ The critical point, however, is that "sovereignty" - whether understood in religious (common ground) or secular (political) terms, or some combination of the two-was itself a form of toleration of territorially-situated religious groups guaranteed through reciprocal treaty obligations.

148. Id. at 84 .

149. Id. See further Benjamin Braude \& Bernard Lewis, Introduction, in Christians and Jews in the Ottoman Empire: The Functioning of a Plural Society 22-23 (Benjamin Braude \& Bernard Lewis eds., Holmes \& Meier Publg. 1982) (noting that in 1856 the Ottoman rulers sided with various reformers wanting to secularize, liberalize and democratize the millet system and use it as the basis for national self-government).

150. See Richard Tuck, The Rights of War and Peace: Political Thought and the International Order from Grotius to Kant 12 (Oxford U. Press 1999) (arguing that it was Hobbes "above all who made clear the relationship between humanism and natural rights, and who demonstrated the link between the older jurisprudence of war and the new political theory"). 
Viewed against this history, the approach of the Ottoman empire to religious toleration bears both several similarities and several fundamental differences. For a number of theological and strategic reasons, the Ottomans were willing to allow non-Muslim religious communities to exercise a substantial measure of internal selfgovernance. The millet system was in effect a group rights model-a "federation of theocracies"-under which each religious community was granted an official "external" legal status and an "internal" right to selfgovernment and autonomy. This meant that relations between the Jewish and Christian millets and the ruling Ottomans were governed by Islamic "public" law. The status and legal capacity of individuals, however, was determined by religious adherence and hence Islamic law (shari'a) did not apply to disputes between non-Muslims. In this way, the millet system permitted an extensive degree of (internal) freedom in both religious and civil matters and ensured relatively peaceful relations between diverse religious communities. Indeed, this conception of group rights has led Kymlicka to argue that the millet system

offers a viable alternative form of religious tolerance to Rawlsian liberalism. It does not deny the obvious lessons of the Wars of Religion, that is, that religions need to coexist. Indeed, the existence of the millets probably saved the Ottoman Empire from undergoing these wars. In fact, this is arguably the more natural form of religious tolerance. The historical record suggests that "in practice, religions have usually felt most violently intolerant not of other religions but of dissenters within their own ranks.” This was true of paganism in antiquity and of leading figures in the English Reformation, such as Thomas More. ${ }^{151}$

Kymlicka's argument concerning rival conceptions of religious toleration and pluralism gives rise to two broad observations. First, the respective histories of the Holy Roman and Ottoman empires suggest a high level of correlation between group rights on the one hand-whether in the form of state sovereignty or autonomous self-governance ("minority rights") — and social stability and the decreased likelihood of violent conflict on the other. ${ }^{152}$ Sovereignty for the various Catholic and Protestant communities in seventeenth-century Europe was the end

151. Kymlicka, Two Models, supra n. 146, at 85 (citations omitted).

152. This is confirmed by recent surveys of ethnonationalist conflict in the world which show that "self-government arrangements diminish the likelihood of violent conflict, while refusing or rescinding self-government rights is likely to escalate the level of conflict.” Will Kymlicka, Western Political Theory and Ethnic Relations in Eastern Europe, in Can Liberal Pluralism be Exported?: Western Political Theory and Ethnic Relations in Eastern Europe 13, 26 (Will Kymlicka \& Magda Opalski eds., Oxford U. Press 2001). 
result of religious civil war and relentless violent struggle against imperial forces. This sovereignty protected an "internal” domain reservé premised on the right to self-governance according to religious confession (cuius regio, eius religio). "External” sovereignty, however, rested on an unstable and evolving conception of formally equal natural rights in a putative state of nature in conjunction with specific treaty obligations assumed at peace conferences. While this conception of external sovereignty removed religious allegiance as a justification for war-and thus achieved the objective of peace and stability between warring Christian communities - it simultaneously established a new "secular" European political order premised on a new autonomous (and belligerent) subject: the sovereign state.

By contrast, the internal dynamics of the Ottoman empire were remarkably stable. As Braude and Lewis have observed:

For nearly half a millennium the Ottomans ruled an empire as diverse as any in history. Remarkably, this polyethnic and multireligious society worked. Muslims, Christians and Jews worshipped and studied side by side, enriching their distinct cultures. ${ }^{153}$

The main reason for this stability and peaceful coexistence was that religious pluralism was officially — that is, publicly-recognized and "tolerated" in the form of legal and political pluralism. Of course, this scheme of toleration existed within a framework of great asymmetry of power and the external "sovereignty" of the millets remained subject to the (descending) dictates of the constitutional structure of the Ottoman empire, as interpreted and applied by the dominant Muslim majority. ${ }^{154}$

153. Braude \& Lewis, Christians and Jews, supra n. 149, at vol. 1, 1. When the Byzantine Empire fell to the Ottomans in 1453 with the taking of Constantinople, the religious independence of Christians was preserved and the Orthodox Church in fact flourished under the Ottomans, who supported them in their conflict with the Western Catholic powers (which the Orthodox Church saw as a greater threat). See Alan Palmer, The Decline and Fall of the Ottoman Empire 28-31 (J. Murray 1992); Evans, Religious Liberty, supra n. 53, at 60.

154. This conception of toleration of religious minorities by a religious majority group did not, however, differ much from the system of "licensed coexistence" in sixteenth and seventeenthcentury Europe. As Kymlicka notes, the

Ottoman restrictions on the building and location of non-Muslim churches were similar to the system of "licensed coexistence" established under the Edict of Nantes (1598). Under that edict, which ended the Wars of Religion, Protestants in France could build new churches only in certain locations, and only with state license.

Kymlicka, Two Models of Pluralism and Tolerance, supra n. 146, at 84. Similarly,

both systems combined toleration of religious worship with discrimination in terms of public office. In the millet system, the non-Muslim communities gained freedom of worship in the 1400s but only achieved full legal equality in 1856. This parallels the growth of toleration in Britain, which adopted the Toleration Act in 1689, but which imposed some legal disabilities on Catholics and Jews until 1829 and 1846 respectively. 
But my point is that the group rights model of legal and political pluralism within the Ottoman empire was a radically different approach to religious toleration compared to the monist, anti-pluralist universalism which ultimately caused the violent fragmentation of the Holy Roman empire into autonomous political (albeit comprehensively religious) units. Both post-Reformation Europe and the Ottoman empire were ascending-descending in structure, ${ }^{155}$ but the nature of the descending strand of justification differed markedly in each case-the one premised on natural law and right reason, the other on the will of The Almighty "being the only sovereign of the universe."156 This is an important point because, for all the weaknesses and historical injustices of the millet system, it suggests that there is more than one approach to the question of toleration of religious pluralism. Many liberal theorists writing on religious toleration, for example, appear to assume that a religiously diverse society was simply impossible before the advent of liberalism. ${ }^{157}$ As Kymlicka notes, however, the "“successful and peaceful practice of toleration' existed in the Ottoman Empire long before England's Toleration Act."

\section{Id. at 98 n. 5.}

155. As Arjomand notes, under the public law of the Muslim lands before the advent of modern constitutionalism the "function of government was not essentially to act as the executive of the sacred law (Shari'a) but to maintain order and rule with justice among the Muslim and nonMuslim subjects (re'aya) so that they could abide by the sacred law according to the religion and/or Muslim school (madhhab) of their choice.” Thus, contrary to both certain Orientalist and fundamentalist schools of thought, the

umma, or community of believers was never the political community. The political community of the Ottoman and Moghul empires contained as many or more non-Muslim as Muslim subjects (and the Safavid empire as many Sunnis as Sh'ites). So much so, that the European travelers in the Ottoman empire mistook the term "subjects" "(re'aya)" to mean Christians.

Said Amir Arjomand, Religious Human Rights and the Principle of Legal Pluralism in the Middle East, in Religious Human Rights in Global Perspective: Legal Perspectives 331, 333-334 (Johan D. van der Vyver \& John Witte, Jr. eds., Martinus Nijhoff Publishers 1996).

156. Gamal M. Badr, A Survey of Islamic International Law, in Religion and International Law, supra n. 53, at 95, 98-99 (citing Joseph Schacht, Islamic Law in Contemporary States, 8 Am. J. Comp. L. 133, 144 (1959)).

157. Kymlicka criticizes Rawls, in particular, for talking about the principle of tolerance as if "there were just one, which he equates with the idea of freedom of conscience." Kymlicka, Two Models of Pluralism and Tolerance, supra n. 146, at 86. Rawls, e.g., has stated that the success of liberal institutions may come as a discovery of a new social possibility: the possibility of a reasonably harmonious and stable pluralist society. Before the successful and peaceful practice of toleration in societies with liberal political institutions there was no way of knowing of that possibility. It can easily seem more natural to believe, as the centuries' long practice of intolerance appeared to confirm, that social unity and concord requires agreement on a general and comprehensive religious, philosophical or moral doctrine.

John Rawls, The Idea of an Overlapping Consensus, 7 Oxford J. Legal Stud. 1, 23 (1987).

158. Kymlicka, Two Models of Pluralism and Tolerance, supra n. 146, at 86. 
The second observation is that neither the Islamic millet system nor the Christian Peace treaties at Augsburg or Westphalia placed an emphasis on individual freedom of conscience. Luther and Calvin were as intolerant as the Roman Church while the patriarchs and rabbis in the Ottoman millets were as conservative and theocratic as the Caliphs. ${ }^{159}$ The move to recognize individual religious liberty would follow only later and would follow different trajectories in each case. In most of Europe, the steady ascent of the liberal democratic tradition would see toleration equated with social contractarian ideas of the right to individual freedom of conscience and liberal "neutrality" on questions of the good. By contrast, in the successor states to the Ottoman empire, the group rights model would be maintained within an overarching framework of Islamic jurisprudence and the public law of the Muslim monarchies. ${ }^{160}$ The former separated, while the latter united, religion and state although in different ways and with different consequences.

In addition to the millets, Muslim and other rulers in the East followed the practice of issuing unilateral grants to Western traders. Known as "Capitulations," these permitted foreigners to establish communities and exercise substantial self-government throughout the Ottoman empire. ${ }^{161}$ As the balance of power shifted from East to West, these privileges increasingly became the means by which the Western European states sought to intervene in the empire to protect the rights of their subjects. Peace treaties between the Ottomans and Austria and Russia also contained obligations to respect the religious liberty of both Catholics and Orthodox Christians. ${ }^{162}$ The rather limited rights of

159. Id. at 83-87.

160. Arjomand, for example, has pointed out that the constitutional and public law of the contemporary Middle East "replaced not the Shari’a but the public law of the Muslim monarchies, especially those of the three early modern Muslim empires: the Ottoman empire in Eastern Europe, the Near East and North Africa; the Safavid - and later Qajar-empires in Iran; and the Mughal empire in India.” Arjomand, Religious Human Rights, supra n. 155, at 331. The public law of medieval and early modern Islam thus recognized a "basic duality of temporal and religious laws," the public law consisting of the "kanun" and the divine law consisting of the shari'a. Id. at 334.

161. This included the exercise of criminal and civil jurisdiction over co-nationals and the right of free and public worship. See Nussbaum, A Concise History, supra n. 63, at 52-58. Note that under Articles III and IV of the First Franco-Turkish Capitulation, Suleiman the Magnificent conferred upon Francis I of France the power to appoint consuls with authority to determine "all causes, suits and differences, both civil and criminal, which might arise between merchants and other subjects of the King." The local Cadi also had no criminal jurisdiction over French subjects and Article VI provided that they "have the right to practise their own religion.” Evans, Religious Liberty, supra n. 53, at 61.

162. See e.g. the Treaty of Carlowitz (1699) and the Treaty of Passerowitz (1718), which confirmed Roman Catholics (Latin rite) in the enjoyment of "whatever privileges the preceding ... Emperors of the Ottomans have favourably granted in their realms, either by earlier 
intercession in these treaties were interpreted broadly by the European powers so as to place both Catholic and Orthodox Christians under their "protection" and to provide a later pretext for intervention on their behalf. Thornberry, for example, has observed that there is a

difference between inter-Christian instruments and the Christian and Turkish treaties in that the former tended to confine protection to ceded territories and the latter were more wide-ranging, applying throughout the Ottoman Empire. ${ }^{163}$

There appear to be two reasons for this difference. First, "minority clauses were in contradiction to the spirit of the law in European states" (but not in "ceded territories") whereas the millet system granted religious freedom to minorities throughout the Empire. ${ }^{164}$ Second, and more significantly, the emergence of the newly "secularized" system of sovereign states in Europe changed the balance of power such that the "European powers could insist and the Ottomans were unable to resist.”165

\section{Enlightenment Discourse in the Eighteenth Century and the Rise of Natural Rights}

As these changes occurred within the emerging European system of states, early classicists such as Wolff and Vattel sought to reconcile the assumed existence of divine or natural law with its applicability in changing circumstances. ${ }^{166}$ They did this, in effect, by assuming natural law to be of a very general nature whose function was to liberate states to "create a society of their liking among themselves."167 This is best seen in the work of Vattel, who applied the classic liberal doctrine of

sacred treaties or by other imperial marks, either by edict or by special mandate." The Treaty of Kutschuk-Kainardji, concluded between Russia and Turkey in 1774, went even further and granted parallel liberties to Orthodox Christians. Evans, Religious Liberty, supra n. 53, at 62-63.

163. Patrick Thornberry, International Law and the Rights of Minorities 29 (Oxford U. Press 1991).

164. Id.

165. Evans, Religious Liberty, supra n. 53, at 64. A similar pattern can be seen later in the nineteenth century when the western powers forced China to accede to the "Unequal Treaties." See Nussbaum, A Concise History, supra n. 63, at 194-195.

166. Emmerich de Vattel, Le Droit des Gens (Albert de Lapradelle ed., Adamant Media Corp. 1916) ch. III, at 9a. Vattel's general argument was that while in civil society each member must yield certain rights to a general body capable of legislation and sanctions, such an idea is inappropriate in the case of the relationship between nations where each State is independent of all the others. See Tuck, Rights of War and Peace, supra n. 150, at 192.

167. Koskenniemi, Apology to Utopia, supra n. 15, at 86. Thus, Vattel's conception of pacta sunt servanda and good faith rested not on religious foundations but on a secular natural law emphasizing reciprocity and reason. Vattel, Le Droit des Gens, supra n. 166, bk. II, ch. 12, § 163. 
politics in inter-sovereign relations. ${ }^{168}$ In the absence of an objective conception of the good life, all that existed were subjective desires upon which society was based. Employing the domestic analogy, Vattel thus posited that the law between states is analogous to the law between individuals in the natural state. States are "super-individuals, thrown in the world to seek their self-interest" and the international community is only an "aggregate of such States and, by itself, has no claim on them."169 Given the Enlightenment assumptions of his work, Vattel therefore believed that both religion and religious practice should be subordinated to the state which, in turn, could "profit" from religion by mustering the "firmest support" of citizens for "lawful authority."170 Conversely, no nation had the right to compel another people to adopt a specific religion. ${ }^{171}$ On the old question of treaty obligations entered into between Christian and non-Christian states, Vattel could thus state in characteristically over-confident eighteenth-century terms:

It is asked whether an alliance can be made with a Nation which does not profess the true religion, whether treaties made with the enemies of Christianity are valid? Grotius has treated the question in sufficient detail. His discussion of it might have been necessary at a time when the fierceness of party strife left still in doubt the principles which it had for a long time caused to be forgotten. Let us hope that the discussion is unnecessary in our day. The natural law is the sole rule of the treaties of a Nation; religious differences are entirely foreign to them. Nations treat with one another as bodies of men and not as Christians or Mohammedans. Their common welfare requires that they be able to treat one another and to rely upon one another in so doing. Any religious doctrine which should run counter to the natural law in this matter would deserve to be rejected; they would not come from the Author of Nature, who is ever the same and true to Himself. ${ }^{172}$

168. For Vattel, nations were formed by civil compacts and thus their obligation of selfpreservation derived from "human act" and not nature. Id. at bk. I, ch. 2, § 16.

169. Koskenniemi, Apology to Utopia, supra n. 15, at 90. See Vattel, Le Droit des Gens, supra n. 166, Préliminaires § 11.

170. Vattel, Le Droit des Gens, supra n. 166, bk. I, ch. 12, § 125.

171.

The horrible idea of spreading religion by the sword is subversive to the Law of Nations and the most terrible scourge of peoples .... While Charlemagne was ravaging Saxony with fire and sword, in order to establish Christianity there, the successors of Mahomet were devastating Asia and Africa, in order to set up the Koran.

Id. at bk. II, ch. 4, § 59 .

172. Id. at bk I, ch. 12, §§ 129-130. 
Even while asserting that the "party strife" of the Wars of Religion was a thing of a distant pre-civilized past, there are passages in Vattel where he prefigures, if only implicitly, a new danger in international relations-

[t]hose ambitious European States which attacked the [native] American Nations and subjected them to their avaricious rule, in order, as they said, to civilize them, and have them instructed in the true religion. ${ }^{173}$

In criticizing Grotius for sanctioning war against those nations said to have violated natural law, Vattel failed to see that the substitution of an ascending-descending conception of sovereignty for a formerly descending conception gave to ambitious and autonomous states not less, and arguably considerably more, "pretexts without number."174 The unity of God had now been eclipsed by the monism of Reason. Enlightenment man and the autonomous sovereign state alike were now at liberty to pursue adventure and exploitation unchained from the constraints of divine law and guided by the certainty and progress of universal reason. ${ }^{175}$

As Max Weber suggested as early as $1906,{ }^{176}$ it is thus important to see the connection between the rise of the modern idea of natural rights in Enlightenment political thought and the period of rapid European expansionism and subsequent encounters with non-European, nonChristian peoples. Both coincided with and propelled the formation and identity of the European nation-state. This period between roughly 1500 and 1900 encompasses a complex series of developments at both the domestic and international levels as first the authority of the Pope and

173. Id. at bk. II, ch. 1 , § 7. See Janis, Religion and the Literature of International Law, supra n. 55 , at 128 .

174.

Did not Grotius perceive that in spite of all the precautions added in the following paragraphs, his view opens the door to all the passions of zealots and fanatics, and gives to ambitious men pretexts without number? Mahomet and his successors laid waste to and subdued Asia to avenge disbelief in the unity of God; and all those whom they regarded as associateurs, or idolaters, were victims of their fanaticism. Vattel, Le Droit des Gens, supra n. 166, at bk. II, ch. 1, § 7.

175. States, for example, are for Vattel the sole judges of their own treaty obligations. If there is a perceived conflict between a treaty's objectively binding nature and State freedom, the State is only under an imperfect duty to interpret the treaty equitably and in good faith. Id. at bk. II, ch. 12 , $\S \S 1591-1570$. The obvious risk of this approach is that a state remains bound only if that is what it wills.

176. Weber famously asserted an ideological link between the rise of Protestantism and the rise of capitalism and saw it as no accident that the first free-market societies developed in the Protestant states of the Netherlands, England and America. Max Weber, The Protestant Ethic and the Spirit of Capitalism (Talcott Parsons trans., Oxford U. Press 1992). 
Emperor, and later that of the King, were progressively limited and the feudal community slowly transformed into sovereign "democratic" States.

I do not wish to discuss this rich and well-trodden history here. I do, however, wish to emphasize the cultural and historical particularity of the so-called revolutionary "Age of Rights." It was the struggle during the English Civil War of 1640-60 between defenders of the monarchy and supporters of a republic under Cromwell that led to the Glorious Revolution in Great Britain and the establishment by the English Bill of Rights in 1688 of a constitutional monarchy. In the following year, John Locke published his Second Treatise of Civil Government which still today remains as the classic statement of the doctrine of natural rights. ${ }^{177}$ It was these Lockean natural rights to life, liberty and property which animated the American War for Independence from British rule between 1775 and 1783 and which found powerful expression in the 1776 Declaration of Independence and 1789 U.S. Bill of Rights. Similarly, it was the American Revolution and the idea of the natural Rights of Man which inspired the French Revolution against the monarchical regime of Louis XVI and saw the passing by the National Assembly of the 1789 Declaration of the Rights of Man and Citizen. In England, America, and France respectively, the struggle for democracy and individual rights resulted in different political structures and varying theories of constitutionalism. But, especially in the United States and France, the idea of the Rights of Man provided the theoretical basis for the emerging notion of a liberal democratic state characterized by the separation of church and state and the protection of individual rights.

The spirit of the Enlightenment thus had a profound impact both on the conception of man in political philosophy and on the conception of the sovereign state in international relations. And as we have seen, these two constellations of ideas have been dynamically interconnected since at least the time of Hobbes through the state-as-individual in a state of nature analogy. What is important to realize, however, is that during this period in no sense did international law seek to recognize or protect the individual right to freedom of conscience. Treaties and juridical accounts of the Law of Nations pertaining to religious freedom were limited to the specific minority guarantees in the Peace of Westphalia

177. As Orend argues, "Locke himself was a strong supporter of the Glorious Revolution, so it is important to note that the book was not just abstract philosophy but also very much a product of its time, almost like a sophisticated political pamphlet justifying the change in government." Brian Orend, Human Rights: Concept and Context 201-202 (Broadview Press 2002). 
and the various Capitulations and Peace treaties entered into between the European states and the Ottoman Empire. Individual liberty of conscience, to the extent it was recognized at all, remained a constitutional question considered in a very few states.

\section{Professional Discourse in the Nineteenth Century and the Rise of Positivism}

As Nussbaum writes, by the early-nineteenth century, international law had become a "science" in the great era of positivism. This meant that that the

conception of the law of nature and the kindred one of just war were to all intents and purposes abandoned-the consummation of a process which ... had started in the eighteenth century. The science of international law was now definitely conceived of as legal or juridical; it was severed from philosophy, theology, and considerations of policy, all of which had been ingredients of the law of nature. Generally, a clear line of demarcation was drawn between the actual law of nations and the law of nations as it ought to be. ${ }^{178}$

International lawyers now saw themselves as working in an era where an objective law grounded in the conditions of life between states had replaced formerly subjective opinions about divine or natural law. Kaltenborn von Stachau, writing in 1847, saw this as the result of three factors: "protestantism, religious freedom, and the separation of law and religion from each other." ${ }^{179}$ The so-called professional discourse of the nineteenth century thus sought to create a more scientific and convincing conception of international order than had been achieved in Vattel's early classical argument. As Koskenniemi argues, this was achieved by trying to counter two deviationist strands of argument within professional discourse. The first was the argument of John Austin (1790-1859) that Vattel's system demonstrated that international law was in fact "only" a form of moral argument. ${ }^{180}$ The second was the

178. Nussbaum, A Concise History, supra n. 63, at 232.

179. Koskenniemi, Apology to Utopia, supra n. 15, at 99 n. 220 (citing Kaltenborn von Stachau, Kritik des Völkerrechts 24-25 (1847)).

180. As Koskenniemi suggests, Austin in his Province of Jurisprudence Determined (1832) argued that only positive law is a proper subject for jurisprudence and that the precepts of international law are "but the opinions of States" and thus such writing is "even at its best (i.e., when descriptive and positivistic) writing about positive morality." Koskenniemi, Apology to Utopia, supra n. 15, at 101. For Austin, the early lawyers such as Grotius and Pufendorf "confounded ... the rule which actually obtains among civilized nations ... with their own vague ideas of international morality as it ought to be.” Id. at n. 234 (quoting John Austin, Lectures on 
argument of Georg Jellinek (1851-1911) and the German historical school that international law was in fact "only" external municipal law. ${ }^{181}$ To mainstream international lawyers, both of these arguments seemed subjective- “Austin's because it assimilated international law with morality (and morality is subjective), Jellinek's because it identified the law with State will (and State will is subjective)."182

The dilemma, then, for the professional mainstream was how to reinterpret the naturalist strand in Vattel's argument-the process by which natural reason leads to natural law-and to develop an account of international law that was truly "objective" and "scientific." It is important to realize that the professionals did this not by abandoning the idea of natural law, but rather by (re)defining it in a way more congruent with State practice. Thus, if the term "international legal positivism" as characteristic of the nineteenth century is understood to mean a fully consensualist or ascending mode of argument, then this understanding is an error. ${ }^{183}$ Professional writing relied on a combination of consensualist and non-consensualist, positivist and naturalist, ascending and descending arguments in an effort to avoid the twin charges of apology and utopia.

In the professionals' argument initially "positivistic" points about consent turn regularly (though silently) into naturalistic ones under the argument from tacit consent, systemic (purposive) coherence or generalization from treaty. Furthermore, the primacy of the State, its "absolute" rights and its will to the law is based on the liberal-naturalist assumption about the primacy of the individual to the society. True, professionals did not class this assumption

Jurisprudence and the Philosophy of Positive Law 74-75 (Lawbook Exch. 1913)) (alterations in original). The Vattelian premise of the equality of states meant that there could be no superiorinferior relation and this led Austin to his famous conclusion that international law is not law "properly so-called." Id. at 102.

181. Jellinek argued that the fact that international law emerges from the State's or nation's will does not necessarily make it a matter of opinion or arbitrary State will. State will can bind itself and the naturalist position that autolimitation is impossible should be rejected. See Koskenniemi, Apology to Utopia, supra n. 15, at 104. By combining State purpose and the nature of international relations, Jellinek attempted to achieve the equivalent in liberal argument to an objective law existing beyond State will.

182. Koskenniemi, Apology to Utopia, supra n. 15, at 105-106. Koskenniemi concludes that Austin was a "moral cognitivist" and Jellinek used "State purpose as an objective telos." Both views are descending and lead beyond liberalism. Id. at 106.

183. Koskenniemi notes that the arguments of many professionals conserved the idea of natural law and even "insisted on the natural character of most international law." The structure of their argument was "identical to that of professional positivists or eclectics, the difference being in syntax, or order of making the descending or ascending points." Id. at 106 . The term "positivism" is, however, open to many interpretations and thus may include certain normativist and sociological strands beyond simple "voluntarism.” Id. at 106-107. 
under necessary natural law as Wolff and Vattel had done. They did not always talk expressly of "fundamental" or "absolute" rights so as to connote naturalism (though they often did). But the descending character of this argument is well manifested in the organization of professional writing which uniformly starts the discussion on substance by discussing the concept of the "State"or even an enumeration of European States. The State-and a set of rights associated with it-is the professional a priori, the transcendental condition from which discourse proceeds and which itself is not subject to discussion. ${ }^{184}$

This strategy of tacit reconciliation had significant implications for the understanding of religious freedom in international law, as is wellillustrated in the work of the nineteenth century British international lawyer James Lorimer (1818-90). While Lorimer claimed that human reason played a central role in identifying the basic tenets of natural law, he ultimately relied on God as the source of that law while at the same time equating Christianity with the highest form of civilization. As Noyes has observed, international lawyers in this period

placed nations whose views they associated with Christianity in a superior position concerning their international legal rights and obligations vis-à-vis certain other nations. Their view of the superiority of this religious system helped them to justify a world in which it was difficult for non-European States, entities and peoples to be entitled to participate fully in an international legal community. Indeed, Lorimer in particular used the "superior" nature of Christianity to justify interference by European States in the affairs of, and even subjugation of, some international actors that did not adhere to Christianity. ${ }^{185}$

Equating the Law of Nations with Christianity did not distinguish Lorimer from other nineteenth-century theorists who adopted a more strictly consensualist, "positivistic” approach. Oppenheim, for example, regarded international law as "essentially a product of Christian civilization" and represented a "legal order which binds States, chiefly

184. Koskenniemi, Apology to Utopia, supra n. 15, at 107. Koskenniemi shows how two professional theorists, Klüber (1762-1836) and de Martens (1845-1900), integrate both of these strands into their arguments. Although they start from opposing positions (the former ascending, the latter descending), they end up in similar doctrinal outcomes. Id. at 108-117 (citing J.L. Klüber, Droit des Gens Moderne de l'Europe (1819); F. de Martens, Traité de Droit International I-III (1883-1884, 1887)).

185. John E. Noyes, Christianity and Late Nineteenth-Century British Theories of International Law, in The Influence of Religion on the Development of International Law 86 (Mark W. Janis ed., Martinus Nijhoff Publishers 1991). 
Christian, into a community." "186 Thus, most non-Christian States were in a separate category for "neither their governments nor their population are at present able to fully understand the Law of Nations and to take up an attitude which is in conformity with all the rules of [international] law."187 In this way, the tacit assumption of the ultimate truth and universality of Christianity stood behind the various "objective" assertions of the tenets of natural reason.

This form of moral reasoning thus constructed the Christian/nonChristian opposition that characterizes the international law of this period. ${ }^{188}$ In similar terms, once one adopts the tacit assumption of the universality not of Christianity but of liberalism, the same logic leads to the liberal/nonliberal distinction which has come to define late modern international legal discourse. Indeed, it has been observed that there is a remarkable congruence between Lorimer's threefold distinction between civilized, barbarian (or half-civilized) and savage (uncivilized) nations, and Rawls's more recent threefold distinction in his Law of Peoples between liberal, nonliberal (decent hierarchical societies), and outlaw (rogue) states. ${ }^{189}$

Woven throughout Lorimer's "science of jurisprudence" is a theory of historical progress which, by associating Christianity with civilization, provides the justification for European imperialism and colonialism. Public international law was at the "current nature and stage of development" a matter primarily for the "civilized" States of Europe. As regards "barbarian” and "savage” peoples, guardianship was the most desirable response. Lorimer thus developed a conception of natural law which explained the "right of national and ethical development and expansion" and "reconcile[d] us to the course of the world's history."190 Natural law, as with all legal and scientific postulates, derived from God, who was infinite in His power and

186. L. Oppenheim, International Law: A Treatise 4, 346 (Lawbooks Exch. 1905). Oppenheim considered religion along with science, art, developed agriculture, industry and trade to be the main interests that define "civilised States." He thus stated: "As the civilised States are, with only a few exceptions, Christian States, there are already religious ideas which wind a band around them.” Id. at 10.

187. Id. at 148 .

188. For an extended analysis of this issue, see Antony Anghie, Finding the Peripheries: Sovereignty and Colonialism in Nineteenth-Century International Law, 40 Harv. Intl. L.J. 1 (1999) (exploring the relationship between positivism and colonialism).

189. See James Lorimer, The Institutes of the Law of Nations: A Treatise of the Jural Relations of Separate Political Communities 93 ff. (Oxford U. 1884). See further Martti Koskenniemi, The Gentle Civilizer of Nations: The Rise and Fall of International Law 1870-1960, at 131 (Cambridge U. Press 2002).

190. James Lorimer, The Institutes of Law: A Treatise of the Principles of Jurisprudence as Determined by Nature 334 (T. \& T. Clark, L. Publishers 1872). 
wisdom. Given that the law of nature was universal, the Law of Nations was itself the law of nature "realized in the relations of separate political communities."191 As understood through the science of jurisprudence, which was to be grasped by human reason as ordered by divine will, international law thus rested "on Divine decrees more stable than the hills" and its premises were "coincident . . . at every point with Christian doctrine." ${ }^{192}$

Much like Jellinek and the German historical school, Lorimer viewed States as separate moral entities-human communities possessing a certain "moral consciousness."193 But unlike Jellinek, Lorimer looked not to a conception of Staatszwecke (natural state purpose) as the basis for an objective, descending set of constraints on State will, but rather to the superior relation between Christianity and natural reason. The full consequences of this move can be seen by comparing Lorimer's conception of international order to that of Pufendorf. While both theorists advanced strongly descending, community-oriented accounts of sovereignty, the conclusions that they drew from these differed markedly. For Pufendorf, the state of nature was a state of peace and self-improvement. ${ }^{194}$ From this he developed his rich account of human sociability which sought to restrain the aggressive and self-interested conduct of states, especially as regards European colonial expansion. For Lorimer, however, writing two hundred years later, the self-evident connection between scientific rationality and the Christian faith led him to advance an account of international law which supported aggressive intervention in nonChristian states in the name of moral progress.

While the fact of interdependence meant that states had a strict duty of mutual recognition, Lorimer posited it was for each state to determine, in the absence of a centralized authority, whether to recognize other states. The existence of a "reciprocating will" was the main criteria for recognition which Lorimer believed was to be determined primarily on the basis of religious belief. Thus,

States adopting secular forms of government that claimed "universal acceptance"... [including] "intolerant monarchies"

191. Lorimer, The Institutes of the Law of Nations, supra n. 189, at 12.

192. James Lorimer, Studies National and International 153, 157 (William Green \& Sons 1890).

193. See Koskenniemi, Gentle Civilizer of Nations, supra n. 189, at 78 (discussing the "idea of moral character as the nucleus of civilized conscience-consciousness" in late nineteenth-century international legal thought).

194. For Pufendorf's theory of sovereignty and criticism of Hobbes, see Samuel Pufendorf, The Law of Nature and Nations II. 3. 20, at 141 (Basil Kennet trans., 5th ed. 1749). 
such as the Roman Empire and "intolerant republics" such as the French Republic of 1793 were examples of States that lacked the requisite "reciprocating will.",195

As regards states organized and governed expressly by religious principles, Lorimer believed that non-Christian states could provide the basis for recognition only if they allowed for the necessary role of human reason. This was because, uniquely among religions, Christianity operated through "indirect revelation" and human reason.

It is Christianity alone which, in opening to humanity a new avenue to the knowledge of God's will, and of those ultimate and absolute laws which lie behind and beyond all religions, does not close the avenue to this knowledge which nature has opened to mankind. In claiming to be a direct revelation to humanity, it does not repudiate the indirect revelation through humanity. On the contrary, it is on its coincidence with the latter, so far as the latter goes, that Christianity mainly bases its claim to our further acceptance. Its divinity is guaranteed to our nature by the divinity which addresses us through our nature. It was as the Son of Man that the Son of God spoke to us; and our consciousness tells us that, in carrying us beyond our nature, the religion which He taught is still carrying us along the lines which our nature indicates. Christianity explains us to ourselves; and the law which it teaches us, in being divine, is not on that account the less, but the more, human law. ${ }^{196}$

This passage captures the joining together of nineteenth century positivist philosophy with the post-Enlightenment secularization of Christian values. ${ }^{197}$ The result was that only religions with the requisite "operative ethical system" could be reciprocally recognized as falling within the category of "States.", Therefore, political recognition

195. Noyes, Christianity, supra n. 185, at 91 (citing Lorimer, Law of Nations, supra n. 189, at 126-133).

196. Lorimer, Law of Nations, supra n. 189, at 114.

197. For an argument that much of the Enlightenment represents the secularization of Christian values, see John Gray, Enlightenment's Wake: Politics and Culture at the Close of the Modern Age, ch. 10 (Routledge 1995). Note also Stuart Hampshire's observation that the "positivist interpretation of history" was widespread in the nineteenth century and suggested that there must be a step-by-step convergence on liberal values, i.e., "our values." "The positivists believed that all societies across the globe will gradually discard their traditional attachments . . because of the need for rational, scientific and experimental modes of thought which a modern industrial economy involves.” Stuart Hampshire, Justice is Strife, 65 Proc. \& Addresses Am. Phil. Assn.19, 24-25 (Nov. 1991).

198. For extensive discussion on the implications of this point, see Noyes, Christianity, supra n. 185, at 92-102. Lorimer, for example, rejected "Mahometan States" as not being entitled to recognition under the law of nations as the "Koran would still have stood between it and the world without, and contradicted its constitutional professions of reciprocating will.” Thus, "[u]nless we 
should be confined to those states whose religions "by conscious or unconscious processes, have been reasoned out from the facts of nature, and which preach the doctrine of 'live and let live,"” while "we must strive to commend to [other nations] the religion in which we believe, by convincing them of its accordance with the promptings of that human nature which is common to them and to us."199

We can see then that Lorimer was not a state of nature theorist. He did not believe that states-once recognized-had equal rights. ${ }^{200}$ As Noyes suggests, for Lorimer the "patent inequality that human reason so clearly revealed must be part of God's natural order" and this led him to an obvious corollary of the inequality of States: the "need to rearrange States' existing relationships to correspond to those suggested by their true power."201 Accordingly, he suggested that the use of force to intervene in the affairs of foreign states is both morally and legally justified because "[a]ggression is a natural right, the extent of which is measured by the power which God has bestowed on the aggressor, or permitted him to develop." 202 To fail to exercise this right was worse even than the "terrible form of war," for the former "would involve the abandonment of progress, whereas the latter secures its attainment, though at a terrible, and perhaps needless, price."203 Similarly, the notion of human progress necessitated guardianship towards "barbarians and savages" and thus provided the moral justification for the colonization of non-European peoples. ${ }^{204}$

Lorimer's conception of international law powerfully illustrates the logic of the professional argument. The positivism of the nineteenth century is premised on the (ascending) primacy of the state while the (descending) limits on state sovereignty are to be determined by the

\footnotetext{
are all to become Mahometans, that is a time which Mahometanism tells us can never come." Lorimer, Law of Nations, supra n. 189, at 124.

199. Id.

200. As Anghie observes, the "existence of a distinction between the civilized and the uncivilized was so vehemently presupposed by the positivist jurists, that the state of nature-and therefore naturalism-becomes epistemologically incoherent because lacking this central distinction.” Anghie, Finding the Peripheries, supra n. 188, at 24.

201. Noyes, Christianity, supra n. 185, at 93.

202. Lorimer, Institutes of Law, supra n. 190, at 332.

203. Id. at 335-336.

204. On the question of colonization, Lorimer stated as follows:

All that can be said is, that at the point at which the rights and duties of recognition cease, the rights and duties of guardianship begin .... Colonisation, and the reclamation of barbarians and savages, if possible in point of fact, are duties morally and jurally inevitable; and where circumstances demand the application of physical force, they fall within necessary objects of war.

Lorimer, Law of Nations, supra n. 189, at 227-228.
} 
objective science of Reason as derived from the "God within Man." As Lorimer himself described his "confession of faith":

I am, then, neither an atheist nor a pessimist. I believe in the reasonableness of omnipotence and in the omnipotence of reason; and, from an absolute point of view, I venture to set no limits either to the scheme of Providence or to the perfectibility of human society. ${ }^{205}$

\section{The Right to Religious FreEdom In the Modern ERA}

Having thus established that international recognition of the concept of religious freedom can be traced back at least to the midsixteenth century, this third and final part briefly sets out my third argument concerning the monitoring and protection of religious liberty in international law in the modern era. Unlike in the previous two parts, my concern here is not to trace a detailed description of relevant historical and doctrinal developments. This has been well-done by many others. ${ }^{206}$ Rather, I seek only to illustrate how, following the failure of the League of Nations minority treaty regime, the recognition of an individual right to freedom of thought, conscience, and religion under the international human rights regime created by the United Nations remains indelibly linked to and shaped by the historical and conceptual arguments discussed above. It is for this reason that contemporary accounts of religious freedom in international law, premised on liberal notions of state neutrality and the public/private divide need to consider more seriously the claims of value pluralism.

\section{A. Paris 1919 and the League of Nations Minorities System}

The modern system for the protection of religious freedom has its origins in the series of minorities treaties drafted at the Paris Peace Conference of 1919 following the end of the First World War. These treaties mark a conscious departure from the Westphalian cuius regio principle of seeking to establish peace and stability through determining the physical boundaries of the State on the basis of religion. The Allies now sought to establish a conceptual apparatus through which attention

205. Id. at 184 .

206. For a useful discussion of the transformation of the right to freedom of thought, conscience and religion from the writings of early thinkers into national law, and ultimately into international law, see Arcot Krishnaswami, Study of Discrimination in the Matter of Religious Rights and Practices, U.N. Doc. E/CN.4/Sub. 2/200/Rev. 1 (1960), reprinted in Religion and Human Rights: Basic Documents 2 (Tad Stahnke \& J. Paul Martin eds., Ctr. for Study of Hum. Rights 1998). 
was switched to exercising both conditionality and multilateral oversight of obligations placed upon States under international law. In this respect, the establishment of the League of Nations represents a double shift: the first from Great Power diplomacy to international action mediated through multilateral organizations; and the second, from nineteenth century practice, as typified by the Treaty of Berlin in 1878, to the contemporary international system.

While the Covenant of the League of Nations did not address religious freedom, the so-called "minorities treaties" drafted in the New States Committee in relation to the newly constituted and enlarged States in Central and Eastern Europe did explicitly address the question of religious liberties. ${ }^{207}$ They continued the tradition of inserting clauses seeking guarantees of certain rights in treaties conferring recognition on new States. The starting point at the League of Nations Conference for the consideration of minority issues was the protection of Jews in Poland and the Polish Treaty thus served as the model for later minorities treaties. As Evans observes, the Polish Treaty immediately exposed a tension which struck at the core of the "national" self-determination principle upon which the post-war settlement was being conducted, and which continues today to be a source of contestation in international law - the difference between a "national" as opposed to an "ethnic, religious or linguistic" minority. On the one hand, Zionists who viewed the Jews to be a "nation" called for the establishment of a Jewish National Home and "national rights" in Central and Eastern European states to protect the culture and religious traditions of Jewish life. On the other hand, those who viewed the Jews as nationals and citizens of the states in which they lived sought more limited "minority" protections against intolerance and discrimination on the basis of religion and religious practices. ${ }^{208}$

For their part, the Poles issued general complaints against the policy of imposing minority obligations on a sovereign state regarding the treatment of its citizens. They further suggested that establishing a system which gave special privileges under so-called "Jewish clauses" would only create further animosity and a "new Jewish problem."209 By

207. For the relevant provisions of these various agreements, see Protection of Linguistic, Racial and Religious Minorities by the League of Nations, League of Nations C.L. 1101927 I.B. 2 (1927). See also Inis L. Claude, Jr., National Minorities: An International Problem (Harv. U. Press 1955); Malcolm D. Evans, Religious Liberty and International Law in Europe 105ff (Cambridge U. Press 2008).

208. Evans, Religious Liberty, supra n. 53, at 105-106.

209. Article 10 sought to ensure that the Jewish community retained full control of its schools, a right not extended to other minorities, who had to rely on the Polish government to ensure their 
emphasizing the elements of Jewish nationalism reflected in the treaty and the precedent it set, the Poles

raised the spectre of the Allies themselves becoming subject to similar forms of minority obligations, a possibility that they had resisted, and were continuing to resist, at the cost of some considerable embarrassment. ${ }^{210}$

One of the central concerns was whether allowing the Jews to control their own schools, as proposed under Article 10, would encourage Yiddish to be used in primary and secondary education. It was felt that this would foster the creation of a State within a State. In a cover letter by Clemenceau accompanying the final text of the Treaty, the Allies thus made clear that the Treaty would impose special protections of only a "minority" rather "national" kind for the Jewish community in Poland.

These clauses have been limited to the minimum which seems necessary under the circumstances of the present day, viz., the maintenance of Jewish schools and the protection of the Jews in the religious observance of their Sabbath. It is believed that these stipulations will not create any obstacle to the political unity of Poland. They do not constitute any recognition of the Jews as a separate political community within the Polish State.... Ample safeguards against any use of non-Polish languages to encourage a spirit of national separation have been provided in the express acknowledgement that the provisions of the treaty do not prevent the Polish State from making the Polish language obligatory in all its schools and educational institutions. ${ }^{211}$

Once the Polish Treaty was concluded, the Allied Powers immediately entered into four other minorities treaties with Czechoslovakia and the Serb-Croat-Slovene State (September 10, 1919), Romania (December 9, 1919), and Greece (August 10, 1920). The obligations contained in these treaties were then placed under the

enjoyment of funding under Article 9 (requiring education to be provided in minority languages). See Annex D to Minutes of 23rd Meeting of the New States Committee in D.H. Miller, My Diary at the Peace Conference vol. 13, 171 (privately published, Appeal Printing 1924). Article 11 specifically protected Jews from being compelled to perform any act which constituted a violation of their Sabbath (with the exception of military service). See Evans, Religious Liberty, supra $\mathrm{n}$. 53 , at $119-120$.

210. Evans, Religious Liberty, supra n. 53, at 120.

211. New States Committee, Minutes, 27th Meeting, Annex C, in Miller, My Diary, supra n. 209, at 220-221. Cf. Advisory Opinion No. 11, Minority Schools in Albania, 1935 P.C.I.J. (Ser. E) No. 11, at 136 (Apr. 6, 1935) (holding that the minorities treaties required "equality of opportunity" for minority groups with majority populations and that this required not just "negative nondiscrimination" but "positive measures" to protect and preserve minority languages, culture and religion). 
guarantee of the League of Nations, which itself came into existence with the entry into force of the League Covenant on January 10, 1920. Minority protections on the Polish Treaty model were further included in the Peace Treaties with Austria, Hungary and Bulgaria; ${ }^{212}$ and the Treaty of Sèvres with Turkey, signed by the Ottomans on August 10, 1920, also contained provisions for the protection of minorities. ${ }^{213}$

Together, these five treaties with particular States involving minority problems, provisions on minorities in general peace treaties with four countries, and declarations made by several States as a condition for their admission to the League became known as the minorities system. As Evans points out, however, it is difficult to defend these instruments as a "system" given the inconsistency of their application. Minority obligations were not uniformly imposed by the victors on the War's losers since the Treaty of Versailles imposed no such obligations on Germany. Nor were Belgium, France or Denmark required to assume minority obligations though they gained territory at Germany's expense. Similarly, nothing was required of Italy, which received areas of the Southern Tyrol and of the Istrian Peninsula. ${ }^{214}$

Given the lack of a uniform system of obligations and the fact that the League itself was little more than a one-sided attempt by the Allied Powers to supervise various "bad risks" in Central and Eastern Europe and parts of the Near East, ${ }^{215}$ it was only a matter of time before it would start to unravel. This undoing was accelerated by the fact that there was no practical way for the League Council to ensure that states fulfilled their obligations regarding the treatment of minorities and it was increasingly difficult even to call states to account before the League for their violations. ${ }^{216}$ Finally, Germany withdrew from the League in 1933, and in 1934, Poland announced that it would no longer cooperate in matters of minority protection. ${ }^{217}$

212. Treaty of St. Germain, Arts. 62-69 (Austria); Treaty of Trianon, Arts. 55-60 (Hungary); Treaty of Neuilly, Arts. 49-57 (Bulgaria).

213. Treaty of Sèvres Arts. 140-150 (Fr.).

214. See Evans, Religious Liberty, supra n. 53, at 143.

215. See C.A. Macartney, National States and National Minorities 289 (Oxford U. Press 1934). As noted above, none of the Allied Powers themselves were prepared to assume reciprocal minority obligations. The failure of the United States to join the League of Nations also contributed significantly to its final collapse.

216. See D.W. Bowett, The Law of International Institutions $17-18$ (4 $4^{\text {th }}$ ed., Stevens 1982$)$ (noting that whether a breach of the League Covenant had occurred, or whether there was an obligation to apply economic sanctions under Article 16(1), was ultimately dependent on each member's view of the situation).

217. See Richard Veatch, Minorities and the League of Nations, in The League of Nations in Retrospect 369, 381 (Walter de Gryuyter ed., UN 1983). 
For the purposes of my analysis, however, it is important not to equate the failure of the League with any inherent failing of the minorities treaty system. That system constituted an important and innovative experiment that had many merits: ethnic, religious and cultural groups across Europe were rehabilitated after the Great War, were able to resist forced assimilation, and were able to both preserve and practice their religion, languages and culture and play a role in the political affairs of their countries. ${ }^{218}$ Furthermore, the methods of mediation, conciliation and adjudication established by the minorities treaties produced some notable successes as well as an impressive jurisprudence on issues of equality and minority rights. Thus:

Despite all the faults and shortcomings, some inherent and others external, the experience of twenty years does not justify the condemnation of a most remarkable experiment: an experiment that could not but share the fate of the political organism in which it lived - the League of Nations itself. ${ }^{219}$

We might conclude, then, by observing that the rationale and objectives of the minority system were closely based on two premises. First, the system assumes that a nondiscrimination principle by itself was insufficient to ensure that individuals belonging to minorities enjoyed legal equality with other nationals of the State. This constitutes an early recognition of the distinction between formal and substantive equality. A second, and closely related, premise was that in order to achieve substantive equality it is necessary to have group-differentiated rights protecting differences in religion, language and culture. These two notions were later articulated by the Advisory Opinion of the Permanent Court of International Justice in the 1935 Minority Schools in Albania case. ${ }^{220}$

\section{B. 1948 Universal Declaration and the UN Human Rights Treaty System}

It is now a matter of history that the League and its minority

218. For a useful discussion, see Nathaniel Berman, "But the Alternative is Despair": European Nationalism and the Modernist Renewal of International Law, 106 Harv. L. Rev. 1792 (1993).

219. Jacob Robinson et al., Were the Minorities Treaties a Failure? 265 (Inst. Jewish Affairs Am. Jewish Cong \& World Jewish Cong. 1943).

220. Minority Schools in Albania 1935 P.C.I.J. (Ser. A/B) No. 64, at 17 (suggesting that the protection of racial, religious or linguistic minorities and the ensuring of "true equality" between a majority and a minority requires "suitable means for the preservation of their racial peculiarities, their traditions and their national characteristics"). 
treaties system failed to guarantee minority rights with devastating consequences. Emerging from the ashes of the Second World War, there was a general consensus amongst the main powers to replace the minority protection treaties with a human rights regime more directly centered on individual rights. It was thought that one reason for the failure of the League system was its emphasis on the differences between minorities, and the use of "special protections" for different groups, which ultimately led to greater tension and opposition between groups. The prevailing sentiment in 1943 was well captured by Under Secretary of State Sumner Welles, when he stated that:

in the kind of world for which we fight, there must cease to exist any need for the use of that accursed term "racial or religious minority".... [I]s it conceivable that the peoples of the United Nations can consent to the reestablishment of any system where human beings will still be regarded as belonging to such "minorities"? ?21

Under the strong leadership of the United States, the United Kingdom and France, a United Nations Commission on Human Rights was established in 1946 to draft a "universal declaration" of human rights. At the hands of drafters such as of René Cassin of France, John Humphrey of Canada and Eleanor Roosevelt of the United States, the Declaration gradually took shape according to two of the central tenets of Western political theory: the normative supremacy of civil and political over economic, social and cultural rights; and the fundamental idea of equality and nondiscrimination as a right pertaining to individuals and not to groups.

The history of the origins and drafting of the UDHR have been well-documented elsewhere and it is not my intention to revisit that literature here. $^{222}$ Rather, I wish only to make some brief observations regarding the tension in the post-War human rights instruments between individual and group rights before turning to the specific right to freedom of religion or belief itself. It is often noted today that neither the UN Charter nor the UDHR contain any group or minority rights provisions and both are premised instead on the nondiscrimination

221. Joel E. Oestreich, Liberal Theory and Minority Group Rights, 21 Hum. Rights Q. 108, 113 (1999) (quoting Sumner Welles, Address by the Under Secretary of State, 8 Dept. St. Bull. 479, 482 (June 5, 1943)) (alteration in original).

222. See e.g. Paul Gordon Lauren, The Evolution of International Human Rights - Visions Seen (U. Pa. Press1998) especially 105-138 ("Visions and Rights Between the Wars") and 172204 ("Peace and a Charter with Human Rights”); Johannes Morsink, The Universal Declaration of Human Rights: Origins, Drafting, and Intent 288-294 (U. Pa. Press 1999). 
principle. $^{223}$ Part of the reason for this was the decisive influence of the Western powers in drafting the Declaration, especially the United States. In the Third Session of the Human Rights Commission, for example, Eleanor Roosevelt argued that "provisions relating to rights of minorities had no place in a declaration of human rights," largely on the basis that "minority questions did not exist on the American continent."224 It was only later when the process began of transforming the Declaration into the legally binding International Covenant on Civil and Political Rights that certain collective rights were (re)introduced into international human rights law. In particular, Article 1 protecting a people's right to self-determination and Article 27 protecting the rights of ethnic, religious and linguistic minorities are today accepted international legal norms. The inclusion of self-determination in both covenants, coupled with Article 27 in the ICCPR, thus reflect recognition of the limitations of the nondiscrimination principle and the need to protect the rights of minority groups and indigenous peoples, not just their physical existence but also their right to a distinct collective identity. ${ }^{225}$

What then is the relevance of this discussion for the right to freedom of religion and belief itself? As suggested above, the covenants' inclusion of both individual and group rights in international human rights law merely reproduces within its structure the dilemmas we have been grappling with without providing a substantive theory of how to resolve actual conflicts either between rights and collective goods or between rights themselves. The law is thus radically indeterminate. On the one hand, we have "peoples" with a right to selfdetermination (Article 1) and "persons belonging to minorities" with the

223. See UN Charter, art. 1, ๆ 3; UDHR, art. 2, ๆ 1. See also ICCPR, art. 2, ๆ 1 \& 26.

224. Summary Record of the Seventy-Third Meeting, UN ESCOR, Comm. on Hum. Rts., 3d Sess., at 5, UN Doc. E/CN.4/SR. 73 (1948). In the previous year, Eleanor Roosevelt made the point that while there were different ethnic and linguistic groups in the U.S., their rights were adequately secured on the basis of individual rights and the nondiscrimination principle. See Working Group on the Declaration of Human Rights, UN ESCOR, Comm. on H.R., 2d Sess., at 1, UN Doc. E/CN.4/57 (1947). For a powerful account of this period in American foreign policy, see Carol Anderson, Eyes Off the Prize: The United Nations and the African American Struggle for Human Rights, 1944-1955 (Cambridge U. Press 2003) (pointing to the "exigencies of the Cold War" and need to camouflage the "the reality of Jim Crow democracy" and the "Colored question" as shaping the U.S. drafting positions).

225. Given these post-1948 developments, Morsink has asked whether today an additional provision modeled on Article 27 of the ICCPR should be added to the Declaration. This would, in his view, correct the "greatest defect of this pivotal document," i.e., the blindness it shares with the UN Charter about the connection that exists between the prevention of discrimination and the protection of minorities. See Morsink, Universal Declaration of Human Rights, supra n. 222. See also Thornberry, International Law, supra n. 163, at 141-142 (suggesting that Article 27 is the "only expression of the right to an identity in modern human rights conventions intended for universal application.”). 
right to enjoy their own culture, profess and practice their own religion, and use their own language (Article 27). On the other hand, every individual has the right to freedom of religion or belief without "distinction of any kind" and the right to equal protection of the law (Articles 2(1) and 26). Straddling these two clusters of norms, we have the right to religious freedom itself incorporating elements of both individual and group rights by protecting (a) "freedom of thought, conscience and religion," and (b) the freedom "either individually or in community with others and in public or private, to manifest ... religion or belief in worship, observance, practice and teaching” (Article 18). At the same time, manifestations of the right may be limited on the basis of both collective goods (public safety, order, health or morals) and other individual rights (the fundamental rights and freedoms of others). The same structure is evident in the subsequent 1981 UN Declaration on the Elimination of All Forms of Intolerance and of Discrimination Based on Religion or Belief, ${ }^{226}$ prompting Donna Sullivan to observe that the "norms stated in the Declaration hold a striking potential for conflict with other rights." 227 Indeed, unlike in other areas of international human rights law such as racial discrimination and women's rights, the level of dissensus among states over the meaning of international norms protecting religious freedom and how exactly to harmonize domestic laws with international standards has been so strong that there have been no comparable moves toward a legally binding convention on religious freedom.

I have written about the complex institutional and foreign policy dimensions of all this elsewhere. ${ }^{228}$ My point here is that whatever we might say about the normative structure of religious freedom in international law, it is clear that neither a nondiscrimination principle nor a group rights approach on its own will suffice. At the same time, it is a matter of historical fact that in the negotiating and drafting of purportedly "universal" human rights standards such as Article 18 of UDHR, not all of today's states or religions either participated in that

226. Resolution Adopted by the General Assembly on Nov. 25, 1981 (on the Report of the Third Committee (A/36/684)) [hereinafter the 1981 Declaration].

227. Donna Sullivan, Advancing the Freedom of Religion or Belief Through the UN Declaration on the Elimination of Religious Intolerance and Discrimination, 82 Am. J. Intl. L. 487, 490 (1988).

228. See Peter G. Danchin, U.S. Unilateralism and the International Protection of Religious Freedom: The Multilateral Alternative, 41 Colum. J. Transnational L. 33 (2002); Protecting the Human Rights of Religious Minorities in Eastern Europe 192 (Peter G. Danchin \& Elizabeth A. Cole eds., Colum. U. Press 2002). 
process or consented to the final result. ${ }^{229}$ These two factors have led to repeated criticisms regarding the essentially "Western" origins of currently dominant conceptions of human rights which, in turn, have spurred challenges to their potential acceptance and application in nonWestern contexts. On this view, human rights are seen as originating in the West; the West is seen as embodying a liberal legal tradition premised on a stridently individualistic account of moral personality; and "universal" rights are thus seen merely as another form, a more modern form, of Western imperialism-universalizing the tenets of a distinct tradition or, in the words of H.P. Glenn, "being illiberal about being liberal, forcing people to be free."230 To deny this is to deny obvious historical facts and the reasonable concerns of those who seek to challenge today's dominance of liberal conceptions of rights. What is needed is a better account of how and why universal Enlightenment and culturally- and religiously-pluralist counter-Enlightenment narratives are so inextricably bound together in rights discourse and what the consequences are for any viable theory of individual toleration in international law.

\section{CONCLUSION}

This Article has argued that any coherent theory of religious freedom in international law must take seriously the historical and doctrinal implications of the problem that was just surfacing for Grotius in the wake of the Wars of Religion, the problem that subsequently faced his successors in the late seventeenth century in their attempts to formulate a "secular" law of nations between warring religious nomoi. The devolution of the respublica Christiana into the jus publicum europaeum set in motion a radically new communitarian project premised on the idea that social order is to be created from the (ascending) subjective free will of individual subjects. As the will of each subject is free, all subjects must stand in a position of equality, freedom, and independence towards each other. The assumption now is that individuals with subjective will are prior to any community between

229. In 1948, most African and Asian states were European colonies and thus did not participate in the drafting of the Universal Declaration. See Virginia Leary, The Effect of Western Perspectives on International Human Rights, in Human Rights in Africa: Cross-Cultural Perspectives 20 (Abdullahi Ahmed An-Na’im \& Francis M. Deng eds., Brookings Instn. Press 1990).

230. H. Patrick Glenn, Legal Traditions of the World 265 (2d ed., Oxford U. Press 2004). See also Bhikhu Parekh, The Cultural Particularity of Liberal Democracy, in Prospects for Democracy: North, South, East, West 156 (David Held ed., Stan. U. Press 1993). 
them. The liberty of the subject is, in this sense, pre-social and there is a denial of any pre-existing natural or objective normative order. As Koskenniemi's work powerfully attests, this is a "pure fact" view of the freedom of the subject which, in the case of the state, imagines sovereignty as preceding the law, an objective normative fact which the law can only take account of. The state's will (and power) is thus external to and constitutive of legal norms. The difficulty, as we have seen, is that we cannot start a system of social order from the existence of "free" individual subjects, now facing the existential choice of creating themselves, without first assuming the existence of prior objective rules which define "subjecthood" and give it normative significance. Unless we do so, we appear to have no objective way to constrain the will, desire or interest of any entity or individual claiming subjecthood. The danger then is that any objective justification of morality will have given way to a hopeless relativism. In the absence of agreed objective rules, the subjectivity of the state must therefore be formally assumed rather than normatively justified.

In the absence of a preexisting normative order, the equality norm can only be defined in formal terms. It is simply assumed that the free and equal exercise of each subject's conscience will be compossible with, not conflict with, the similar exercise of each other individual's conscience. For as soon as there is a conflict between two formally equal subjects' liberty, that norm will need to be given a substantive "external" meaning that prefers one subject's conception of freedom over that of the other. But as soon as this is done, it will mean treating one subject's preferred substantive view of freedom of conscience unequally. The norm itself thus appears only remotely sustainable if - as I have suggested historically is the case - all members of the political community have the same general background understanding of a pre-existing normative order (which, of course, contradicts the initial premise.) That understanding is based on the transcendental Christian order, which has now devolved into an intersubjective "secular" or "liberal" nomos constituted by independent and autonomous legal subjects.

This soon-to-be invisible background conception of Christian morality provides the normative source for the liberal argument's tacit need to override particular individual ideals about the desirable limits of autonomy or kinds of community through, for example, doctrines of "natural" rights and the public-private divide. The liberal subject is now imagined as possessing a (subjective) "inner" or "private" sphere of religious conscience that is absolutely "free," and an (objective) 
"external" or "public" sphere of secular reason that is independent of any particular beliefs or context and is thus capable of overriding the subjective will of deviant or "unreasonable" subjects in cases of conflict. While religious conviction is in this sense agent-relative, reason is assuredly agent-neutral. A doctrine of fundamental rights is what demarcates the boundary between these two spheres and prevents the legal order from encroaching on the freedom of the subject. But this strategy, once again, requires the assertion of certain pre-existing deontological moral norms (rights) ascertainable through reason which the very existence of states as differently-situated, autonomous legal subjects would appear to deny. The story of religious freedom in international law, in other words, suggests that the reasoning inherent in rights discourse is not as "agent-neutral" as envisaged by an Enlightenment conception of contextless reason, but is itself ineliminably "agent-relative.,"231

The critical question then is how under this conception of international law the liberty of a state that adheres to or advances a "religious" or other comprehensive view of the good is properly to be determined. Such a state's identity as a subject derives not from an initially (ascending) conception of subjective will, but from a (descending) conception of a pre-existing normative order. From this starting point, individual conscience cannot be "free" in the strongly subjective sense assumed by liberal theory but instead is subject to the dictates of an, apparently now eclipsed, divine order. On this view of the "situated" subject, the pre-secular world is already vested with a normative metaphysical higher law that secular law must at least recognize and tolerate. The difficulty, of course, is that this pre-legal Christian normative order now appears subjective. It is not possible to explain in an agent-neutral way why differently-situated states should be constrained against their (subjective) will according to norms derived

231. This notion is central to Alasdair MacIntyre's thesis of the failure of the Enlightenment project to provide an autonomous justification for morality. For MacIntyre, the Enlightenment disengages human beings from this [prior] communal and metaphysical-religious context and thereby robs them of their practice-immanent (as seen from the Aristotelian perspective) and practice-transcending (as seen from the Augustinian-Thomistic perspective) telos as it attempts to justify morality on the basis of a contextless reason of persons robbed of all particularity. Being without ethical substance, this attempt fails and results in a mélange consisting of the ruins of past conceptions of morality, from which the existing "emotivist" culture draws the conclusion that there are no moral obligations at all for such detached persons.

See Rainer Forst, Contexts of Justice: Political Philosophy beyond Liberalism and Communitarianism 203 (John M.M. Farrell trans., U. Cal. Press 2002) (citing MacIntyre, Whose Justice, supra n. 1). 
from this pre-existing moral order. It is this recognition which spurs the need for an intersubjective norm of coexistence and religious toleration which accepts the separate existence of states as legal subjects. But in thus reasoning from certain objective external norms, there can be no pre-configured public-private divide in the form of a (subjective) inner sphere of conscience and an (objective) external deontological sphere of reason. Rather, any norm of coexistence must flow from the fact that states stand as different culturally and religiously-situated subjects in a context-sensitive relationship of not formal but complex equality.

The secular order of international law, is premised on a fraught dialectic between subject and object. The law remains in the grip of Cartesian anxiety over the ultimate, objective truth of foundationalist epistemology: i.e., the explanation of "objective" knowledge as a relation between a knowing subject and an object that can either be a "fact" or a "norm." The liberal subject adopts a realist view about its factual existence as a knowing subject but is unable "objectively" to explain such subjectivity or justify constraints on its freedom in its relations with other subjects other than according to a pre-existing framework of ideas and facts. This position contradicts the initial premise of individual freedom. The comprehensively religious subject, on the other hand, adopts an idealist view of a pre-existing transcendent normative order that denies subjective individual freedom but is unable "objectively" to explain how that order can be grasped without its own subjectivity being constructive of the object perceived. ${ }^{232}$ This contradicts the initial premise of an external immanent moral order. The liberal subject thus appears subjective and apologist about facts while the religious subject appears subjective and utopian about norms. While these two perspectives-mirroring our two narratives and strands of objectivity-appear to be opposed, they cannot exist without each other. From this seemingly endless series of oscillations, the only notion of objectivity that emerges is one of a fragile and circumstantial consensus derived through an intersubjective hermeneutics and philosophy of critical praxis.

What this means is that in the absence of an international authority supervening on differently-situated subjects, there can be no declared or authoritative meaning of religious freedom as an international norm. Rather, such meaning must evolve over time as states interact and exert pressure for convergence towards each other's positions. If this is correct, we are faced with a situation of genuine value pluralism in 
international law. The great difficulty with the liberal claim to have achieved such a reconciliation a priori by means of a fixed, Kantian algebra of compossible and adequate rights is that while a descending conception of God has, at least since the middle of the seventeenth century, become eclipsed by the dawn of an enlightened Age of Reason, a solely descending conception of Reason is itself incompatible with a commitment to freedom of religion. Rawls's conception of moral personality - of the human person as a free agent with certain moral powers-is in this respect no less controversial and fraught with contradictions and antinomies than Locke's conception of human equality in the eyes of God, the taking away of which "tho but even in thought, dissolves all."

In the post-Westphalian liberal order, Public Reason and Autonomous Moral Personality must do the work formerly done by God. The concept of human rights must bear the load of straddling between claims to freedom and the demands for order. It should come as no surprise, then, that modern human rights jurisprudencefunctioning in an increasingly diverse and pluralistic world of religious and secular belief systems and claims-contains within it all the oppositions, dualisms and contradictions of these competing conceptions of objectivity. The demands of value pluralism in international law, however, do not require rejecting the liberal project or modernity's commitment to values of individual freedom and equality. Rather, value pluralism suggests the need for sensitivity to the enormous diversity in normative settlements, both within and between different ways of life, and recognition of the complex intersubjective (and thus transformative) narrative of cultural and religious pluralism which is integral to the very structure of the liberal project. Once we come to terms with the fact that both states and individuals pursue not only different ends, whether religious or secular, but also ends with different and disparate shapes, we will come to accept that an abstract, universal right to freedom of religion or belief cannot entail formally equal or uniform rights at a more concrete level but leads instead to a conception of complex freedom and equality in which the rights of differently-situated subjects will inevitably turn out to differ in detail. 